\title{
Regulatory Standards Applicable or Relevant to the Independent Hanford Environmental Surveillance and Oversight Program
}
S. E. King
P. L. Hendrickson
J. Belfiglio
M. R. Siegel
R. W. Elliott
M. G. Woodruff

March 1990

Prepared for the U.S. Department of Energy under Contract DE-AC06-76RLO 1830

Pacific Northwest Laboratory

Operated for the U.S. Department of Energy

by Battelle Memorial Institute 


\title{
DISCLAIMER
}

This report was prepared as an account of work sponsored by an agency of the United States Government. Neither the United States Government nor any agency thereof, nor Battelle Memorial Institute, nor any of their employees, makes any warranty, expressed or implied, or assumes any legal liability or responsibility for the accuracy, completeness, or usefuliness of any information, apparatus, product, or process disclosed, or represents that its use would not infringe privately owned rights. Reference herein to any specific commercial product, process, or service by trade name, trademark, manufacturer, or otherwise, does not necessarily constitute or imply its endorsement, recommendation, or favoring by the United States Government of any agency thereof, or Battelle Memorial Institute. The views and opinions of authors expressed herein do not necessarily state or reflect those of the United States Government or any agency thereof.

\author{
PACIFIC NORTHWEST LABORATORY \\ operated by \\ BATTELLE MEMORIAL INSTITUTE \\ for the \\ UNITED STATES DEPARTMENT OF ENERGY \\ under Contract DE-ACO6-76RLO 1830
}

Printed in the United States of America

Available to DOE and DOE contractors from the

Office of Scientific and Technical information, P.O. Box 62, Oak Ridge, TN 37831; prices available from (615) 576-8401. FTS 626-8401.

Available to the public from the National Technical information Service,

U.S. Department of Commerce, 5285 Port Royal Rd., Springfield, VA 22161.

NTIS Price Codes, Microfiche A07

Printed Copy

\begin{tabular}{|c|c|c|c|}
\hline Price Code & Page Range & Price Code & Page Range \\
\hline $\mathrm{A} 02$ & 1.10 & A15 & $326-350$ \\
\hline $\mathrm{A} 03$ & 11.50 & A16 & $351-375$ \\
\hline $\mathrm{A} 04$ & $51-75$ & A17 & $376-400$ \\
\hline A05 & $76-100$ & A18 & $401-425$ \\
\hline$A 06$ & $101-125$ & A19 & $426-450$ \\
\hline $\mathrm{A} 07$ & $126-150$ & A20 & $451-475$ \\
\hline $\mathrm{A} 0 \mathrm{~B}$ & $15 t-175$ & A21 & $476-500$ \\
\hline$A 09$ & $176-200$ & A22 & $501-525$ \\
\hline Ato & $201-225$ & $\mathrm{~A} 23$ & $526-550$ \\
\hline A11 & $226-250$ & A24 & $551-575$ \\
\hline$A 12$ & $251-275$ & A25 & $576-600$ \\
\hline At3 & $276-300$ & A99 & 601-Up \\
\hline A14 & $301-325$ & & \\
\hline
\end{tabular}


PNL-7292

UC -630

\section{REGULATORY STANDARDS APPLICABLE OR RELEVANT TO THE INDEPENDENT HANFORD ENVIRONMENTAL SURVEILLANCE AND OVERSIGHT PROGRAM}
S. E. King
J. Belfiglio(a)
R. W. Elliott $(a)$
P. L. Hendrickson
M. R. Siege 1
M. G. Woodruff

March 1990

Prepared for the U.S. Department of Energy under Contract DE-AC06-76RLO 1830

Pacific Northwest Laboratory

Richland, Washington 99352

\footnotetext{
(a) Davis Wright Tremaine Bellevue, Washington
} 
, 


\section{ABSTRACT}

The authors reviewed federal and state statutes and regulations, as well as Department of Energy (DOE) orders and other guidance material, for potential applicability to the environmental surveillance program conducted for the Hanford site by the Pacific Northwest Laboratory (PNL). There are no federal or state statutes or regulations which are directly applicable to the environmental surveillance program. The requirements and scope of this program are largely set by DOE orders. However, other regulatory schemes, while not directly applicable to the environmental surveillance program, are important insofar as they are indicative of areas of regulatory concern and direction. Because of the evolving nature of environmental regulations, this area needs to be closely monitored for future impact on environmental surveillance activities. 


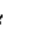

. 


\section{EXECUTIVE SUMMARY}

The purpose of this report is to identify and review requirements found in federal and state statutes and regulations and in Department of Energy (DOE) orders that may impact the environmental surveitlance program at Hanford. Pacific Northwest Laboratory (PNL) conducts the environmental survei]lance program for the Hanford site, pursuant to DOE orders, to assess the impact of Hanford operations on the onsite and offsite environment.

In general, there are no federal and state statutes and regulations that are directly applicable to PNL's environmental surveillance program. Several regulatory schemes impose general surveillance requirements for Hanford. Specific requirements for the environmental surveillance program are largely found in relevant DOE orders. It should be understood that the environmenta] surveillance program conducted by PNL is just one facet of environmental activities at Hanford. Numerous federal and state requirements apply directly to other DOE-supported activities at Hanford. While environmental statutes and regulations are not usually directly relevant to environmental surveillance activities at Hanford, several are discussed in this report because knowledge of them will be useful to those who are developing the scope and goals of the program. Such knowledge may also assist in identifying areas where information collected by PNL's environmental surveillance program can be used to meet other requirements of various environmental statutes and regulations.

We recognize the distinction established by DOE orders between effluent monitoring, which is the general responsibility of the Westinghouse Hanford Corporation at the Hanford Site, and environmental surveillance, conducted by PNL. We do discuss some effluent monitoring requirements, but only to set the context for the environmental surveillance program and to indicate areas of regulatory concern.

DOE Order 5400.1 establishes the requirements for and sets the general scope of environmental surveillance at DOE facilities. Accordingly, developments related to this Order should be closely monitored. 
Other statutes and regulations are important insofar as they are indicative of areas of regulatory concern and direction. Because of the nature of past and current Hanford operations, regulations related to radionuclides are a primary concern. For instance, Environmental Protection Agency's (EPA's) new National Emission Standards for Hazardous Air Pollutants (NESHAP) regulations pertaining to air emissions from DOE facilities are very relevant to the environmental surveillance program. In addition, EPA and U.S. Nuclear Regulatory Commission (NRC) regulations governing waste management activities, while not containing specific monitoring requirements, do include overall dose limits for members of the public and can be useful to evaluating the impacts of Hanford operations. DOE Orders 5400.3, 5400.5, 5820.2A, and draft Order $5400 . X Y$ are also especially relevant to the environmental surveillance program.

With respect to nonradioactive substances, evolving EPA and state regulatory programs related to toxic emissions to the air and surface water can indicate areas of regulatory concern related to the surveillance efforts at Hanford. These programs will probably expand over the next several years and should influence data gathering and data analysis within the environmental surveillance program.

Finally, compliance with the requirements of the Resource Conservation and Recovery Act (RCRA), the Comprehensive Environmental Response, Compensation, and Liability Act (CERCLA), and the Tri-Party agreement among DOE, EPA, and Washington State will require extensive environmental sampling and analysis. While compliance in this area does not set specific requirements for the environmental surveillance program, opportunities to integrate the compliance programs with the surveillance activities should be fully explored. Such integration could improve the quality of information produced and increase the cost-effectiveness of the programs.

More specifically, a number of related requirements contained in the federal Clean Water Act, the Safe Drinking Water Act, and their state counterparts are relevant to onsite environmental surveillance. These include the state monitoring of ambient surface water quality for the Columbia River and the regulatory levels for surface water quality established by EPA and 
Washington State under these acts. PNL's environmental surveillance for radionuclides in surface water may assist with determining Hanford's compliance with applicable standards.

Similarly, there are few regulatory requirements that apply directly to environmental surveillance for air quality at the Hanford Site. Washington State Department of Ecology and the Benton-Franklin-Walla Walla Counties Air Pollution Control Authority can order ambient air monitoring if needed to assure compliance with state or federal ambient air standards. Ambient air monitoring may be needed to support any future "prevention of significant deterioration" permit applications. In addition, surveillance of air quality is required to ensure compliance with exposure standards for airborne radionuclide emissions. As with the regulatory scheme for surface water, the remainder of the air monitoring requirements are related directly to effluent monitoring, but may be relevant to the substance of PNL's environmental surveillance program for Hanford. 


\section{$\underline{\text { LIST OF ABBREVIATIONS }}$}

AEA Atomic Energy Act

ARAR applicable or relevant and appropriate requirements

ATSDR Agency for Toxic Substances and Disease Registry

CAA Clean Air Act

CFR Code of Federal Regulations

CERCLA Comprehensive Environmental Response, Compensation, and Liability Act

CPP CERCLA past practice (units)

CWA Clean Water Act

DCG Derived Concentration Guide

DOE U.S. Department of Energy

DOE-RL U.S. Department of Energy, Richland

DSHS Department of Social and Health Services

EPA U.S. Environmental Protection Agency

FR Federal Register

HLW high-level waste

HRS hazard ranking system

HSWA Hazardous and Solid Waste Management Act

LLW low-level waste

MCL maximum contaminant level

MCLG maximum contaminant level goal

NAAQS national ambient air quality standards

NESHAP national emission standards for hazardous air pollutants

NPDES National Pollutant Discharge Elimination System 


$\begin{array}{ll}\text { NPL } & \text { National Priorities List } \\ \text { NRC } & \text { U.S. Nuclear Regulatory Comnission } \\ \text { OSWER } & \text { Office of Solid Waste and Energency Response } \\ \text { PNL } & \text { Pacific Northwest Laboratory } \\ \text { PSD } & \text { prevention of significant deterioration } \\ \text { PUREX } & \text { plutonium-uranium extraction facility } \\ \text { RCRA } & \text { Resource Conservation and Recovery Act } \\ \text { RCW } & \text { Revised Code of Washington } \\ \text { RI/FS } & \text { remedial investigation/feasibility study } \\ \text { RPP } & \text { RCRA past practice (units) } \\ \text { SARA } & \text { Superfund Anendments and Reauthorization Act } \\ \text { SIP } & \text { state implementation plan } \\ \text { SDWA } & \text { Safe Drinking Water Act } \\ \text { TRU } & \text { Transuranic (waste) } \\ \text { TSD } & \text { treatment, storage or disposal (facility) } \\ \text { USC } & \text { U.S. Code } \\ \text { WAC } & \text { Washington Administrative Code } \\ \end{array}$




\section{CONTENTS}

ABSTRACT ..................................

eXeCUtive SUMMARY .................... v

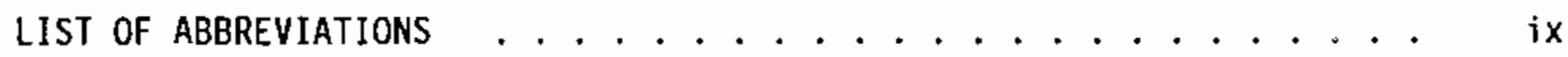

1.0 INTRODUCTION . . . . . . . . . . . . . . . . . . 1.1

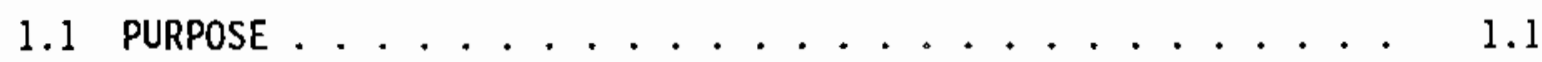

1.2 BACKGROUND . . . . . . . . . . . . . . 1.2

1.3 SCOPE . . . . . . . . . . . . . . . . . 1.3

1.4 CONTENTS . . . . . . . . . . . . . . . . . . 1.4

2.0 SURFACE WATER QUALITY STANDARDS . . . . . . . . . . 2.1

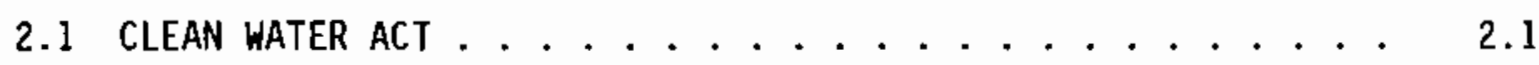

2.1.1 Ambient Water quality Standards . . . . . . 2.2

2.1.2 Effluent Standards ............. 2.5

2.1 .3 Nonpoint Sources. . . . . . . . . . . 2.9

2.1.4 011 and Hazardous Substance Standards . . . . . 2.9

2.2 SAFE DRINKING WATER ACTS . . . . . . . . . 2.9

2.2 .1 Purpose .................. 2.10

2.2.2 Monitoring Requirements for Public Water Systems . . 2.11

2.3 DOE ORDER $5400.1 \ldots \ldots \ldots \ldots \ldots \ldots \ldots$

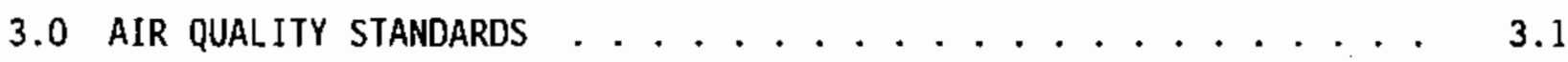

3.1 CLEAN AIR ACT . . . . . . . . . . . . . . . 3.2

3.1.1 Ambient Air Quality Standards ......... 3.2

3.1.2 Effluent Air Quality Standards ......... 3.3

3.2 DOE ORDER $5400.1 \ldots \ldots \ldots \ldots \ldots \ldots . \ldots . \ldots . \ldots . \ldots$

4.0 RADIOLOGICAL CONTROL STANDARDS . . . . . . . . . . 4.1 
4.1 BASIC REGULATORY CONCEPTS FOR RADIOLOGICAL PROTECTION . . . . 4.1

4.2 RADIATION EXPOSURE AND CONCENTRATION LIMITS . . . . . . 4.2

4.2.1 Airborne Radionucl ide Emission Standards . . . . . 4.2

4.2.2 Radionuclide Emission Standards for Water . . . . 4 4.3

4.2 .3 All Media . . . . . . . . . . . . . 4.5

4.3 STANDARDS GOVERNING WASTE MANAGEMENT . . . . . . . . 4.6

4.3.1 Environmental Protection Agency . . . . . . . . 4.6

4.3.2 Nuclear Regulatory Commission Regulations . . . . . 4.7

4.3 .3 DOE Orders . . . . . . . . . . . . . 4.8

4.4 MONITORING REQUIREMENTS . . . . . . . . . . . . . . . 4.9

4.4.1 Airborne Radionuclide Emissions ......... 4.9

4.4 .2 Water Monitoring . . . . . . . . . . 4.10

4.4.3 State Monitoring for Licenses and Registrants . . . 4.11

4.4 .4 DOE Orders ................. 4.12

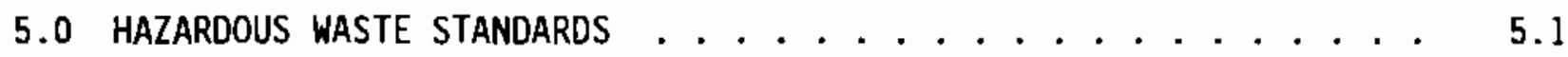

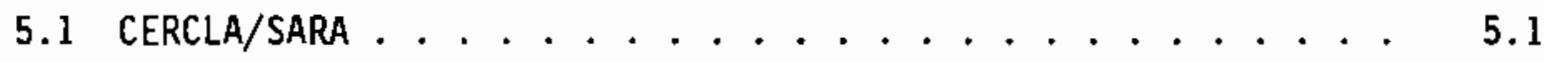

5.1.1 Monitoring Requirements . . . . . . . 5.2

5.1.2 Emergency Planning and Community Right-to-Know

5.2 FEDERAL RESOURCE CONSERVATION AND RECOVERY ACT . . . . . 5.5

5.2.1 Hazardous Waste Management . . . . . . . 5.6

5.2 .2 RCRA Corrective Action ........... 5.7

5.2.3 RCRA Monitoring Requirements . . . . . . . . 5.7

5.3 TRI-PARTY AGREEMENT . . . . . . . . . . . . . 5.8

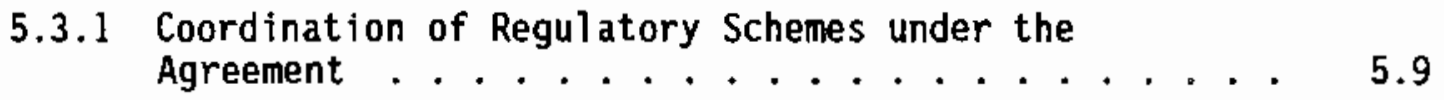


5.3.2 The Action Plan Approach . . . . . . . . . 5.9

5.3.3 Monitoring Requirements Under the Agreement and Action Plan .............. 5.10

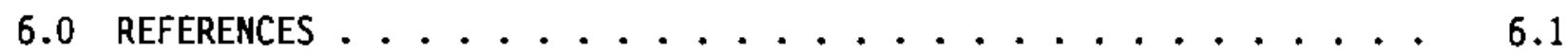
APPENDIX A - BASICS OF ENVIRONMENTAL LAW . . . . . . . . . . . A.1 APPENDIX B - REFERENCE LIST FOR RELEVANT REGULATORY MATERIAL . . • . B B.1 


\section{TABLES}

2.1 List of Toxic Pollutants Under Section 307 of the Clean Water Act . . . . . . . . . . . . . . . 2.4

2.2 The 126 Priority Pollutants of the Clean Water Act . . . . . . 2.7 


\subsection{INTRODUCTION}

This report discusses environmental statutes, regulations and agency guidance that may impact environmental surveillance at the Hanford Site. It supports the Hanford Site's comprehensive environmental surveillance and oversight program, which is organized and implemented by the Pacific Northwest Laboratory (PNL). The program is operated for the Department of Energy's Richland 0perations Office (DOE-RL) by PNL's Office of Hanford Environment.

Environmental surveillance is conducted to assess the impact of Hanford operations on the onsite and offsite environment. Under DOE Order 5400.1, an environmental surveillance program must satisfy one or more of the following:

- verify compliance with applicable environmental laws and regulations

- verify compliance with environmental commitments made in National Environmental Policy Act (NEPA) documentation or other official DOE docunents

- establish baselines of environmental quality

- provide a continuing assessment of pollution abatement programs

- identify and quantify new or existing environmental quality problems.

The environmental monitoring program is discussed more fully in the 1988 annual environmental report for the Hanford Site (Jaquish and Bryce 1989).

\subsection{PURPOSE}

The primary purpose of this report is to identify environmental statutes, regulations, orders, and guidance documents which are directly applicable to PNL's environmental surveillance program for Hanford. This report is also intended to identify regulatory standards and programs which, while not directly applicable to the environmental surveillance program at Hanford, are nonetheless relevant to the program's operation. This type of relevant regulatory standards can assist those responsible for PNL's environmental surveillance program to make that program more effective and responsive to regulatory needs and interests. In addition, relevant technical standards may 
provide guidance in areas in which there are no directly applicable standards (Keller et a1. 1989). The Safe Drinking Water Act, for example, prescribes standards for drinking water systems, yet these standards can and have been used to evaluate the general quality of surface water and groundwater that is not a source of drinking water. Because many environmental regulations do not define specific requirements or identify quantitative standards for environmental surveillance programs, such relevant but not directly applicable information may be useful.

Because of the complexity of environmental regulations and the frequency with which they change, readers are encouraged to consult the regulatory source material directly. The necessary references are provided in this report.

\subsection{BACKGROUND}

In general, DOE orders, rather than statutory and regulatory mandates, establish the requirements of PNL's environmental surveillance program at Hanford. Statutes and regulations do, however, indicate areas of regulatory concern that can help determine the nature of the environmental surveillance program.

DOE Order 5400.1 defines environmental monitoring to include both environmental surveillance and effluent monitoring. Environmental survejllance is defined by DOE Order 5400.1 as "the collection and analysis of samples, or direct measurement, of air, water, soil, foodstuffs, biota, and other media from DOE sites and their environs for the purpose of determining compliance with applicable standards and permit requirements, assessing radiation exposures of members of the public, and assessing the effects, if any, on the environment." Effluent monitoring is defined by DOE Order 5400.1 as "the collection and analysis of samples, or the measurements of liquid and gaseous effluents for the purpose of characterizing and quantifying contaminants, assessing radiation exposures of the public, providing a means to control effluents at or near the point of discharge, and demonstrating compliance with applicable standards and permit requirements." At Hanford, effluent monitoring is generally the responsibility of the Westinghouse Hanford Corporation. 
Regulating agencies and the regulated community are both responsible for monitoring the environment. These activities can entail the monitoring of direct effluent streams from facilities as well as the ambient air, water, and soit conditions. An example of the first type of monitoring, carried out by the regulated community, are the Resource Conservation and Recovery Act requirements for monitoring of groundwater at treatment, storage, or disposal facilities. An example of the latter type of monitoring, generally carried out by regulating agencies, is the monitoring of ambient surface water under the Clean Water Act.

Few legal requirements directly affect the nature of PNL's environmental surveillance program at Hanford. As discussed in greater detail in subsequent portions of this report, the regulated community (DOE and its contractors) has relatively few requirements to conduct general monitoring of the ambient environment. The requirements for monitoring effluent streams are numerous; however, under the DOE scheme, these do not directly affect PNL's responsibilities in the conduct of environmenta] surveillance for Hanford.

However, any environmental surveillance program for the Hanford Site would benefit by an awareness of the general ambient monitoring programs conducted by regulatory agencies. The nature and content of ambient monitoring efforts, as well as other specific effluent monitoring requirements, could help guide and set priorities for PNL's environmental surveillance program at Hanford. For example, substances that are of particular concern to regulatory agencies should be included in the surveillance program and, in many cases, emphasized.

\section{$1.3 \quad \underline{\mathrm{SCOPE}}$}

In this report we address the applicable and relevant standards and guidance for environmental monitoring under the Clean Water Act; the Safe Drinking Water Act; the Clean Air Act; the Comprehensive Environmental Response, Compensation and Liability Act (CERCLA); the Resource Conservation and Recovery Act (RCRA); the Hanford Federal Facility Agreement and Consent Order (TriParty Agreement); and DOE orders. We also address related Washington State environmental statutes. The fundamentals of environmental law are summarized 
in Appendix A. Appendix B provides a reference list for the most relevant environmental statutes, regulations, and other regulatory material.

We do not discuss how Hanford is complying with these standards; rather, we present applicable and relevant standards to be used by decisionmakers and technical staff in designing and operating an environmental surveillance and oversight program.

As defined by DOE Order 5400.1, environmental monjtoring consists of both environmental surveillance and effluent monitoring. We focus on environmental surveillance; effluent monitoring is discussed in detail only when it has some potential relevance for environmental surveiliance.

ReguTatory programs for groundwater monitoring and NEPA compliance are reviewed in Keller, Schmidt, and Selby (1989) and King (1989), respectively.

\subsection{CONTENTS}

In this report, environmental standards and guidance are generaliy discussed according to the environmental media in which pollutants are regulated. Each chapter presents an overview of the environmental laws, their purpose, their relationship to environmental surveillance, and their applicable or relevant standards and guidance. Chapter 2.0 discusses the regulatory schemes under the Clean Water Acts and the Safe Drinking Water Acts (federal and state), plus DOE Order 5400.1's specific environmental surveillance requirements for water. Chapter 3.0 discusses air quality standards under the federal and state Clean Air Acts and DOE Order 5400.1. Chapter 4.0 discusses radiological standards, as they appear in various regulatory and DOE programs. Chapter 5.0 discusses RCRA/CERCLA/Tri-Party Agreement monitoring. Appendix A provides a framework for understanding the environmental laws, regulations, consent orders, and DOE orders discussed in this report. Appendix $B$ provides a quick reference list of statutes, regulations, and DOE orders most relevant to PNL's environmental surveillance program. 


\subsection{SURFACE WATER QUALITY STANDARDS}

Environmental monitoring of surface waters on or near the Hanford Site to determine the effects of onsite activities is motivated by two factors: protection of human health and the environment, and compliance with environmental laws and regulations. This chapter, therefore, not oniy includes statutory and regulatory requirements applicable to surface water monitoring, but also standards and criteria that, while not directly applicable to Hanford, may be relevant to the monitoring program.

of particular interest to environmental surveillance at the Hanford Site are 1) the ambient water quality standards, the biological monitoring requirement under the national pollutant discharge elimination system (NPDES), and the evolving toxics control program of the Clean Water Act; 2) the drinking water standards of the Safe Drinking Water Act; and 3) the general DOE requirements in DOE Order 5400.1 for environmental surveillance of water.

During 1988, surface water samples were collected from four sites on the Columbia River and from three onsite surface ponds to determine the impact of Hanford operations on surface water quality (Jaquish and Bryce 1989).

\subsection{CLEAN WATER ACT}

The Clean Water Act (42 USC 7401 et seq.) was enacted in 1970 and most recently amended in 1987. Its purpose is to "restore and maintain the chemical, physical and biological integrity of the nation's waters." The 1987 amendments, and the revised water quality standards they require, are expected to result in more stringent regulation of surface water quality than has occurred in the past (Arbuckle et a1. 1989), through greater control of toxics and nonpoint source pollution.

This section describes the ambient and effluent water quality programs under the federal clean Water Act. Because of its limited relevance to Hanford operations, requirements of the "dredge and fill" program under Section 404 of the Clean Water Act are not addressed. 
Pursuant to Section 402 of the Clean Water Act, the Washington State Department of Ecology (Ecology) has been authorized by EPA to implement the NPDES program in Washington State, except for federal facilities such as the Hanford Site. Even when EPA retains authority, the State plays a role by certifying that issuance of an NPDES permit will not violate Washington's water quality standards of state law, or waiving the State's right for such certification.

The Clean Water Act controls water pollution by setting standards that regulate

- the quality of the ambient water itself

- effluents discharged to the ambient water.

Although EPA and Ecoiogy monitor ambient water quality themselves, water quality standards can be useful in setting the parameters of the environmental surveillance program at Hanford. Effluent standards are described as the "amount of pollutants that can be released legally from a specific source." The effluent standards discussion in this chapter emphasizes biological monitoring and recent developments in toxics control.

\subsubsection{Ambient Water Quality Standards}

Section $304(a)(1)$ of the Clean Water Act requires EPA to publish and update ambient water quality criteria that reflect the latest scientific knowledge on the identifiable effects of pollutants on public health and welfare, aquatic life, and recreation. The most recent of these publications is Quality Criteria for Water, or the "Gold Book, "which was published in 1986. Among other things, these criteria deal with "conventional" pollution measurements such as turbidity, bacterial count, and PH. EPA has published established updated criteria for bacteria (51 FR 8012, March 7, 1986), chloride (53 FR 19028, May 26, 1988), and selenium (53 FR 177, January 5, 1988).

EPA's water quality criteria provide guidance for determining regulatory requirements. The criteria have regulatory impact only after they have been adopted in a state water quality standard. 
Under Section 303 of the Clean Water Act, states are directed to adopt ambient water quality standards for waters within their boundaries, subject to review and approval by EPA. The criteria may be narrative (descriptive) or quantitative. States have the flexibility either to adopt the EPA standard or to use a site-specific criterion, if this substitution can be justified to EPA. EPA's policy, however, has been to disallow state standards that are not as stringent as the federal guidelines (Findley and Farber 1985).

The process for adopting the water quality criteria begins with classifying the waters of the state according to designated uses (fisheries, recreation, etc.). In Washington State, Ecology has provided the following classifications: Class AA (extraordinary water quality), Class A (excellent), Class $B$ (good), and Class C (fair). Ecology also provides a lake classification. These standards are set forth in the Washington Administrative Code (WAC 173201-045). The water quality of the stretch of the Columbia River that contains the Hanford Reach (Grand Coulee Dam to the Washington-Oregon border) is designated as Class $A$, corresponding to these designated uses: water suppty, stock watering, fish and shellfish habitat, wildlife habitat, recreation, and commerce and navigation.

Once the states have classified their waters, they are to develop ambient water quality criteria protective of the designated uses for each class of water (40 CFR 131). The standards (ClasS A with a special temperature provision) for the Grand Coulee-to-border stretch of the Columbia River are provided in Table B.1 of Jaquish and Bryce (1989). The states have generally assigned quantitative standards for conventional water measurements. Only recently has regulatory attention turned to quantitative standards for toxics control. Washington State has adopted quantitative water quality criteria for 25 toxic substances (no radionuclides); EPA's 1986 water quality criteria and other information are used to determine concentration limits for other toxics (WAC 173-201-047). EPA states that water quality criteria for toxics can serve as the basis for several different regulatory actions. The criteria can be either adopted as ambient standards by states under Section 303 of the 


\section{IABLE 2.1. List of Toxic Pollutants Under Section 307 of the Clean Water Act}
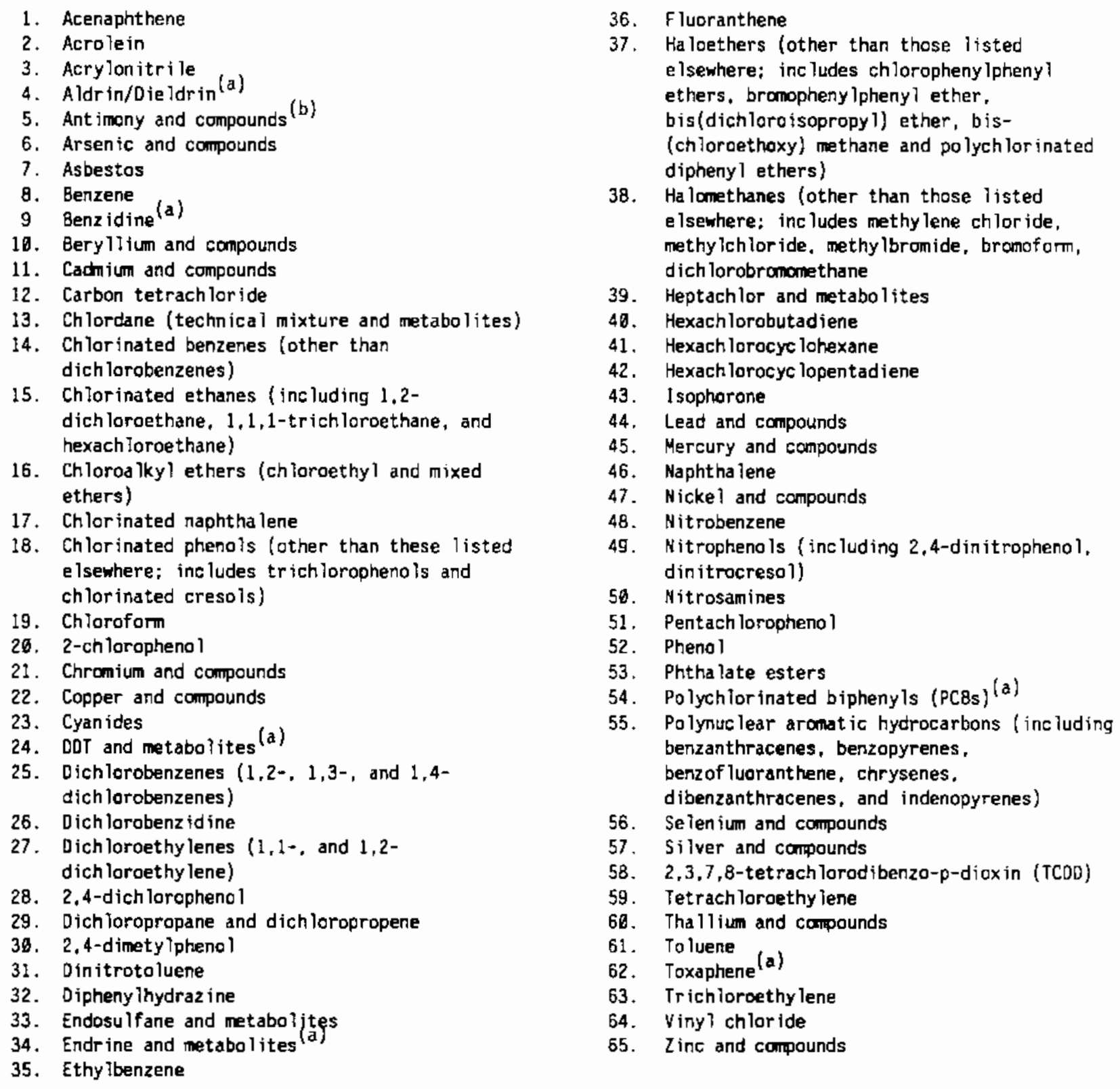

(a) Effluent standard promulgated (40 CFR Part 129).

(b) The term "compounds" shal1 iлclude organic and inorganic compounds. 
Clean Water Act, used for "water quality-based" effluent limitations under Section 302 (see below), or adopted as toxic pollutant effiuent standards under Section 307.

State radionuclide standards for ambient water quality are discussed in Chapter 4.0 of this report.

\subsubsection{Effluent Standards}

Under Section 302 of the Clean Water Act, point-source discharges of pollutants to waters of the United States are prohibited, unless authorized by an NPDES permit. The NPDES program sets effluent limits, standards and concentrations to achieve water quality standards or to attain/maintain specified water quality. Uniform standards have generally been promulgated for industry categories and are based on technological control of pollutants through the "best technology economically achievable." Program requirements are listed in 40 CFR 122 through 125. EPA recently announced its intention to review and promulgate new effluent guideline regulations for a number of industrial groups (55 FR 80, January 2, 1990). This $p 1$ an, however, does not appear to directly affect monitoring activities for the Hanford Site.

DOE-Richland Operations (DOE-RL) holds one NPDES permit from EPA for effluent discharge from eight different point sources on the Hanford Site (a number of which were associated with $\mathrm{N}$-Reactor, now in "cold standby"). This permit is currently being reviewed by EPA (Jaquish and Bryce 1989). Conditions of the permit require the monitoring and reporting of flow rate, suspended solids, temperature, $\mathrm{pH}$, and other items at these eight outfall locations.

NPDES permit holders such as DOE-RL are required to have a biological monitoring program that provides data to evaluate the impact of the discharge on the freshwater or marine biota, demonstrates compliance with applicable water quality standards, and measures toxic substances in the discharge [40 CFR 125.62(a)]. Westinghouse-Hanford conducts this biological monitoring program for the Hanford Site.

In addition, 40 CFR 125.62 requires that the water quality monitoring program 1) provide data for evaluating compliance with water quality 
standards, and 2) measure the presence of toxic pollutants. 40 CFR 122 requires that toxic pollutants in the effluent be reported.

EPA is addressing the toxics problem in its NPDES program through the introduction of "water quality-based permit limitations" for toxic pollutants. For its NPDES program, EPA has established a toxics control strategy (49 FR 38000, September 26, 1984) and a toxics control program (54 FR 23868, June 2, 1989).

Both focus on 65 toxic pollutant classes listed under Section 307 of the Clean Water Act (Table 2.1), from which EPA derived 126 "priority pollutants" (see Table 2.2). A regulatory program that provides quantitative standards for specific toxics is being developed. When available, the toxics standards should be evaluated to determine whether they are pertinent to Hanford Site operations and environmental survejllance.

40 CFR 129 provides toxic pollutant effluent standards and prohibitions. Currently, there are national standards for aldrin/dieldrin, DOT, endrin, toxaphene, benzidine, and PCBs.

\section{Water Quality-Based Effluent Limits}

EPA established a national policy for the development of water qualitybased permit limitations for toxic pollutants (40 FR 9016, March 9, 1984). The water quality-based permit standards are to be used when effluents under current permits are causing or have the potential to cause a violation of ambient water quality standards. EPA recentiy pub]ished procedures which provide that water quality-based effluent standards are to be developed by the states and EPA, in consultation with the regulated cominunity (54 FR 23868 , June 2, 1989). A determination of the need for limiting discharges is made through a procedure outlined in 40 CFR 122.44 (d)(1).

\section{Individual Control Strateqies}

Under Section 304(1) of the 1987 Clean Water Act amendments, states must

- list waters for which ambient water quality standards witl not be achieved

- identify point sources of "priority pollutants" (see Table 2.2) that violate ambient water quality standards 


\section{IABLE 2.2. The 126 Priority Pollutants of the Clean Water Act}

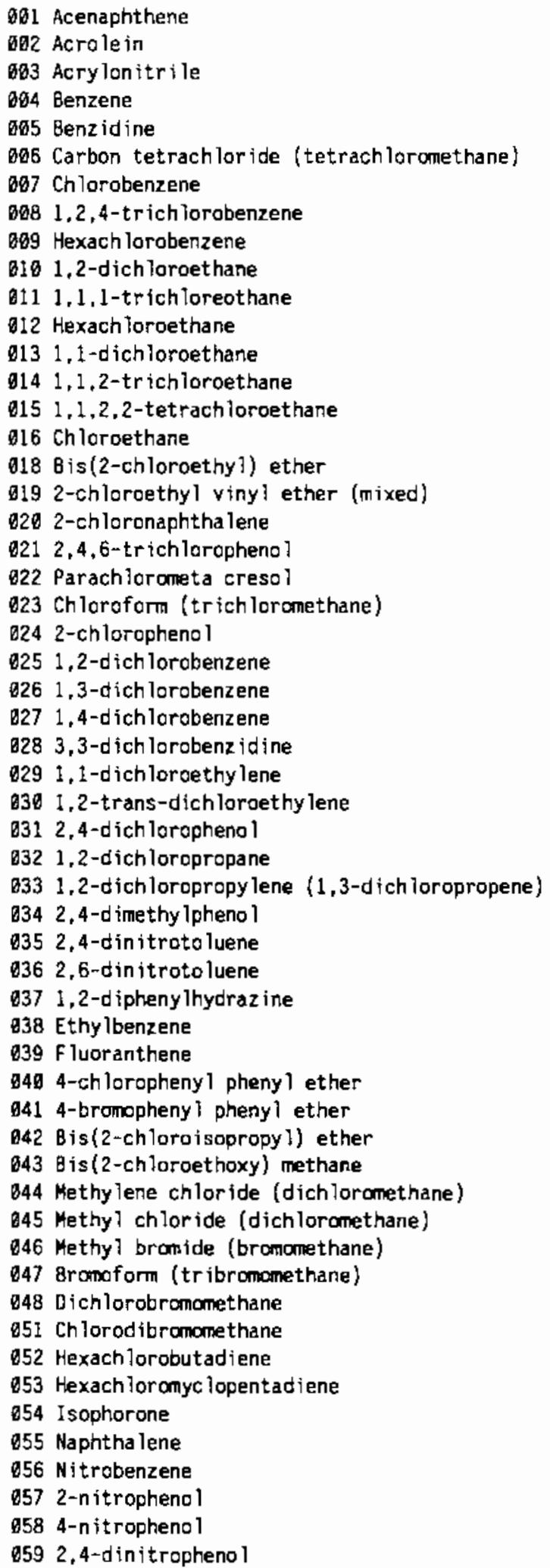

960 4,6-dinitro-o-cresol

$061 \mathrm{~N}-\mathrm{n}$ itrosod imethylamine

$062 \mathrm{~N}-n i t r o s o d i p h e n y l a m i n e$

$063 \mathrm{~N}-n$ itrosodi-n-propylamin

064 Pentachlorophenol

065 Pheno?

066 Bis(2-ethylhexy1) phthalate

067 Buty] benzyl phthalate

$068 \mathrm{Di}-\mathrm{N}$-Butyi Phtha late

069 Di-n-octyl phthalate

070 Diethy] Phthalate

071 Otmethyl phthalate

072 1,2-benzanthracene (benzo(a) anthracene

073 Benzo(a)pyrene (3,4-benzo-pyrene)

074 3,4-Benzof luoranthene (benzo(b) fluoranthene)

075 11,12-benzof luoranthene (benzo(b) fluoranthene)

076 Chrysene

077 Acenaphthylene

078 Anthracene

979 1,12-benzoperylene (benzo(ghi) perylene)

080 Fluorene

081 Phenanthrene

082 1,2,5,6-dibenzanthracene (dibenzo(h) anthracene)

683 Indeno $(, 1,2,3-c d)$ pyrene (2,3-o-pheyny lene pyrene)

084 Pyrene

085 Tetrach loroethy lene

086 Tolvene

887 Trichloroethy lene

$B 88$ Vinyl chloride (chloroethylene)

890 Aldrin

691 Chlordane (technical mixture and metabolites)

Q92 4,4-00T

$0934,4-D D E(p, p-D D X)$

094 4,4-DDD ( $p, p-T D E)$

095 Alpha-endosulfan

096 Beta-endosulfan

Q97 Endosulfan sulfate

998 Endrin

Q99 Endrin aldehyde

160 Heptachlor

181 Heptachlor epoxide (BHC-hexachiorocyc lohexane)

102 A lpha-BHC

103 Beta-BHC

184 Gama-BHC (1indane)

105 Deita-BHC (PCB-polychlorinated biphenyls

106 PC8-1242 (Aroch lor 1242)

107 PCB-1254 (Arochlor 1254)

108 PCB-1221 (Arochlor 1221)

199 PCB-1232 (Arochlor 1232) 
IABLE 2.2. (contd)

110 PCB-1248 (Aroch lor 1248)

111 PCB-1260 (Arochior 1260)

112 PCB-1016 (Arochior 1016)

113 Toxaphene

114 Ant imony

115 Arsenic

116 Asbestos

117 Beryllium

118 Cadmium

119 Chromium

\author{
120 Copper \\ 121 Cyanide. Total \\ 122 Lead \\ 123 Mercuty \\ 124 Nicke 1 \\ 125 Se len ium \\ 126 Silver \\ 127 Tha Ilium \\ 128 Zinc \\ $1292,3,7,8$-tetrachloro-dibenzo-p-diox in (TCOD)
}

- develop and implement "individual control strategies" for each such point source (54 FR 246, January 4, 1989; 54 FR 23868, June 2, 1989).

EPA's water quality criteria and effluent guidelines focus on priority poliutants. Individual control strategies must require reductions in the discharge of priority pollutants from the offending point sources.

\section{Whole Effluent Toxicity Testing}

Section 303 (c) of the Clean Water Act directs states to adopt "specific numerical" criteria for all pollutants listed as toxic under Section 307. However, if numerical criteria are not available, the toxics criteria are to be based on biological monitoring or assessment where controls on individual poliutants in the effluent streams do not adequately protect water quality. Biological monitoring under the Clean Water Act is often referred to as "whole effluent toxicity testing," or biomonitoring.

An EPA publication, The Technical Support Document for Water QualityBased Toxics Control (EPA 1985) provides recomended values for whole effluent toxicity. It describes methods for toxicity testing in the permitting process and provides a detailed technical explanation of biological and chemical techniques to assess and control toxic pollutants and toxicity (54 FR 23868 June 2,1989 ).

\subsubsection{Nonpoint Sources}

Nonpoint source pollution is another area of legislative attention in the 1987 Clean Water Act amendments, and regulatory efforts are just now being 
directed at this area. Section 319 of the CWA requires that each state prepare a report to 1) identify its navigable waters that are not expected to attain or maintain water quality standards without additional actions to control nonpoint source pollution, 2) identify categories of nonpoint sources that add significant pollution to the navigable waters identified under item $1,3)$ describe a process for identifying "best management practices" to control each category of nonpoint source poliution identified under item 2 , and 4) identify and describe state and local programs for controlling nonpoint source pollution.

\section{1 .4 0il and Hazardous Substance Standards}

Section 311(b) of the Clean Water Act provides a policy against discharges of $0 i 1$ or hazardous substances. Under this section, EPA developed regulations (40 CFR 116) designating hazardous substances that present an "imminent and substantial danger to the public health and welfare including fish, shellfish, wildlife, shorelines, and beaches." At 40 CFR 117, the list of hazardous substances is accompanied by "reportable quantities," which are those quantities (in pounds and kilograms) that EPA has determined may be harmful.

Section 311 (b) further prohibits the discharge of $0 i 1$ or hazardous substances to the navigable waters of the United States. Offshore and onshore facilities that discharge oil or hazardous substances in violation of regulations must notify the appropriate government agency.

40 CFR 110.6 prohibits the discharge of oil "in such quantities as may be harmfu1." 40 CFR 110.3 defines "harmful quantities" as discharges that violate applicable water quality standards or that cause a film or sheen on the surface of the water.

\subsection{SAFE DRINKING WATER ACTS}

The Safe Drinking Water Act (42 USC $300 f$ et seq.) requires that operators of public drinking water treatment systems monitor water quality. The Safe Drinking Water Act applies to both surface and underground sources of drinking water. Such monitoring for Hanford Site water supply systems is conducted by 
the Hanford Environmental Health Foundation. Local municipalities monitor the water supply for the Tri-City area. Although not directly applicable to the Hanford Site environmental surveillance program, the technical standards of the Safe Drinking Water Act may be pertinent to environmental surveillance because they are often used as indicators of general water quality.

The Safe Drinking Water Act's regulatory scheme is described in Keller, Schmidt, and Selby (1989). This discussion will, therefore, only briefly summarize the regulatory program, including regulatory updates since January 1989 [the end of the period covered in the Keller, Schmidt, and Selby (1989) report].

\subsubsection{Purpose}

The purpose of the Safe Drinking Water Act is to protect public health by establishing drinking water standards, regulating injections of fluids and waste into wells, and providing authority for special programs to protect aquifers. This section will briefly discuss only the drinking water standards.

Part B of the Safe Drinking Water Act authorizes EPA to adopt national primary and secondary drinking water regulations for public water systems. The primary drinking water regulations are enforceable standards intended to protect public health. Under the primary drinking water regulations, EPA has established maximum contaminant levels (MCLs) for certain inorganic chemicals, organic chemicals, radionuclides, turbidity and microbiological contaminants (40 CFR Part 141), as well as maximum contaminant level goals (MCLGs) for other contaminants ( 40 CFR Part 141, Subpart F). The most recent proposed additions to these standards are at 54 FR 22062 (May 22, 1989). MCLs apply to the free-flowing outlet of the ultimate user of a public water system.

EPA has also promulgated national secondary drinking water regulations that are not federally enforceable but are intended as guidelines for the states (40 CFR 143). These regulations govern drinking water contaminants that primarily affect aesthetic qualities, in contrast to the public health considerations underlying primary drinking water standards. 
Because EPA has approved Washington's program, drinking water standards are enforced by the Department of Health and local health departments under RCW 43.20.050 and the public water supply regulations at WAC 248-54. The state MCLs established at WAC 248-54-175 are at least as stringent as the federal MCLs at 40 CFR 141. The state regulations address design of public water systems, water quality (including monitoring), and water system operations. Part 4 of WAC 248-54 sets forth state monitoring requirements and MCLs. Table 3 of WAC 248-54 specifically summarizes minimum monitoring requirements.

\subsubsection{Monitoring Requirements for Public Water Systems}

The national primary drinking water regulations establish comprehensive monitoring and analytical requirements for the contaminants listed in 40 CFR 141. In genera1, requirements vary according to whether the water system is designated community or noncommunity, and whether the source is surface water or groundwater. Washington State has established four classes of public water systems, depending on the number of services and whether the population served is permanent or transitory.

EPA requires monitoring for contaminants classes subject to MCLs, including certain radionuclides, inorganic chemicals, organic chemicals, microbiological contaminants and turbidity. These monitoring requirements are briefly sumarized below. The state monitoring requirements generally parallel those of EPA and are not described separately in this section, except when there are important differences.

EPA has recently proposed monitoring requirements for approximately 100 synthetic organic chemicals and inorganic chemicals not regulated by primary drinking water regulations (54 FR 22062, May 22, 1989).

\section{Inorqanic Chemical Monitoring}

Yearly monitoring of arsenic, barium, cadmium, chromium, lead, mercury, nitrate, selenium, silver and fluoride is required for community systems using surface water, and at three-year intervals for those using ground water. Public notification is required when the average of four analyses exceeds the MCL for the substance in question. The regulations specify methods for analyzing the listed substances [40 CFR $141.23(\mathrm{f})]$. 
On May 22, 1989, EPA proposed national primary and secondary drinking water standards for asbestos, barium, cadmium, chromium, mercury, nitrate, nitrite, and selenium (54 FR 22062). In addition, EPA proposed compliance monitoring requirements for community and nontransient systems, including monitoring frequency and analytical methods.

\section{Organic Chemical Monitoring}

EPA requires all community water systems using surface water to be monitored at least every three years for organic chemicals that fall within the chlorinated hydrocarbons and chlorophenoxys groups (40 CFR 141.24). The regulations contain complex monitoring requirements for volatile organic compounds, such as benzene, vinyl chloride, and carbon tetrachloride, for which there are MCLs. Sampling of total trihalomethanes is also required under 40 CFR 141.30. Sampling frequency and methods are provided for all organic substances of concern.

Washington's monitoring requirements for organic chemicals generally parallel those of the EPA. Additionally, the State requires monitoring for pesticides such as endrin, lindane, methorochlor, toxaphene and chlorophenoxys.

EPA has recently proposed national primary and secondary drinking water standards for 30 synthetic organic chemicals (54 FR 22062, May 22, 1989).

\section{Microbiological and Viral Contaminant Monitoring}

Suppliers for community water systems must take coliform density samples periodically and in numbers proportionate to the human population served by the system. Suppliers for non-community systems must sample coliform bacteria each calendar quarter that the system provides water to the public.

EPA recently published MCLGs for Giardia and Legionella viruses, heterotrophic bacteria, and total coliform bacteria (54 FR 27486 and 27544, June 29, 1989). This amendment of 40 CFR 141 and 142 also requires disinfection as a treatment technique for all public water systems, whether the source is surface water or groundwater. 


\section{Turbidity Monitoring}

EPA requires daily turbidity sampling (40 CFR 14l.22). The State can reduce the frequency for noncommunity systems if it determines that doing so will not pose a risk to public health. Turbidity monitoring is required only where water is obtained from surface sources.

EPA recently published limits on turbidity as criteria for determining whether a public water system is required to filter and whether any required filtration is adequate (54 FR 27486, June 29, 1989).

\section{Special Monitoring}

EPA has imposed special monitoring requirements for organic chemicals listed at 40 CFR 141.40. These chemicals include chloroform and certain compounds found in petroleum products, such as toluene, xylene and ethylbenzene. The new monitoring requirements are to be phased in between January 1, 1988, and January 1,1991 . Special monitoring is also required for sodium and corrosivity.

\subsection{DOE ORDER 5400.1}

This Order prescribes requirements for water monitoring by any environmental surveillance program sponsored by DOE. Section IV. 8 of the Order states that monitoring ambient water quality serves to confirm compliance with the Clean water Act. The Order states that ambient water quality monitoring should be conducted via a network of fixed stations to establish well-defined histories of physical, biological, and chemical conditions of local water bodies and sediments. Analysis of data from this network should support

- characterizing trends in the physical, chemical, and biological condition of the waters

- establishing baselines of water quality

- continually assessing water pollution control programs

- identifying new water quality problems

- detecting, characterizing and reporting unplanned releases and their effects on water quality. 


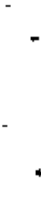




\subsection{AIR QUALITY STANDARDS}

This chapter reviews standards for the environmental surveillance of air quality other than for radionuclides. Radiological air-quality standards are provided in Chapter 4.0.

The basic authority for the establishment of air quality standards is the federal Clean Air Act and regulations issued by EPA under authority of this Act. The State of Washington implements federal standards and requirements through the Washington Clean Air Act, which is administered by Ecology. The Washington Clean Air Act provides for the formation of local and regional air pollution control authorities. The Hanford Site is within the jurisdiction of the Benton-Franklin-Walla Walla Counties Air Pollution Control Authority (the "Authority"). DOE has also published orders that are intended to implement applicable air quality standards and requirements at its sites. This chapter is divided into various subdivisions of the regulatory program. (Appendix $A$ describes the legal framework for environmental law and may be useful as a reference.) The federal Clean Air Act is expected to be amended significantly in 1990, so legislative developments should be tracked.

There is currently a significant amount of air quality surveillance at Hanford. In 1987 radioactivity in the air was sampled by a network of continuously operating air samplers at 21 locations on the Hanford Site, 14 locations near the Site perimeter, 9 locations in nearby communities, and 6 locations in distant communities (Jaquish and Bryce 1989). Nitrogen dioxide was sampled at eight onsite locations and one offsite location. Total suspended particulates were sampled at one onsite location.

of specific relevance to PNL's environmental surveillance program is DOE Order 5400.1, which directs DOE sites to develop and maintain an ambient air quality monitoring program. In addition, monitoring is needed to ensure compliance with the radionuclide exposure standards of EPA and the State. Ambient air monitoring will be needed to support "prevention of significant deterioration" (PSD) permit applications. Ecology and the Authority can order ambient air monitoring if they consider it necessary to ensure compliance with state or federal ambient air standards. 


\subsection{CLEAN AIR ACT}

The basic statute for regulating air quality in the United States is the Clean Air Act, a complex statute with many detailed provisions. The air quality program which EPA has set up under these provisions is discussed below. Federal, state, and local agency implementation of these programs is required.

The Clean Air Act provides standards for both ambient and effluent quality. It regulates air quality by first determining the level of air quality for a given region (airshed zoning), then working backwards to set emission standards for sources in that region (Findley and Farber 1989).

\subsubsection{Ambient Air Quality Standards}

The primary program governing ambient air quality is the national ambient air quality standards (NAAQS). Section 109 of the Clean Air Act directs EPA to establish national primary and secondary air quality standards for pollutants "which may reasonably be anticipated to endanger public health or welfare." EPA is required to prepare an air quality criteria report for each listed pollutant to address its health effects.

Congress required EPA to set primary ambient air quality standards to protect public health with an adequate margin of safety and secondary standards to protect public welfare from any known or anticipated adverse effects. Effects on welfare are defined in Section 302(h) of the Clean Air Act to include "effects on soils, water, crops, vegetation, manmade materials, animals, wildlife, weather, visibility and climate, damage to and deterioration of property, and hazards to transportation, as well as effects on economic values and on personal comfort and well being."

EPA has issued national ambient air standards for sulfur oxides, particulate matter, carbon monoxide, ozone, nitrogen dioxide, and lead (40 CFR 50). The primary and secondary NAAQS for nitrogen dioxide, ozone, and carbon monoxide are the same. States are required to maintain an air quality surveillance system for measuring ambient concentrations of the listed pollutants (40 CFR 58.20). Reference methods for determining ambient air concentrations for each pollutant are contained in the appendices to 40 CFR 50 . Procedures 
for approval of alternative testing methods are at 40 CFR 53. Ecology issued supplemental ambient air standards for particulate matter (WAC 173-470), sulfur oxides (WAC 173-474), and f7uorides (WAC 173-481).

Section 107 of the Clean Air Act directs EPA to classify interstate or intrastate areas as air quality control regions for the attainment and maintenance of NAAQS. The Hanford Site is located in the South Central Washington Intrastate Air Qua]ity Control Region (40 CFR 81.189), which consists of Benton, Franklin, Kittitas, Klickitat, Walla Walla, and Yakima counties [also known by EPA as Air Quality Control Region number 230 (40 CFR 81, Appendix A)]. Within Region 230, particulate matter has been classified as a high priority pollutant (priority I); and sulfur oxides, nitrogen dioxide, carbon monoxide, and ozone have been classified as low priority pollutants (priority III) (40 CFR 52.2471). Ambient air quality in Region 230 is better than NAAQS for particulate matter and sulfur oxides; Yakima is not in attainment for carbon monoxide, but the rest of Region 230 is (40 CFR 81.348; 81.2479). Ambient air quality for nitrogen dioxide and ozone is in the category of "cannot be classified or better than national standards." Unclassifiable areas are treated as attainment areas, i.e., areas that either meet or exceed ambient air standards (Sive and Friedman 1987).

Sections 107 and 110 of the Clean Air Act give states primary responsibility for assuring their air quality through development of state implementation plans that provide for attainment of NAAQS. State implementation plans are the means by which states enforce effluent/emission controls to meet NAAQS standards (Randle 1989). A discussion of Washington's plan is provided at 40 CFR 52, Subpart WW (40 CFR 52.2470 through .2498); major portions have been approved by EPA (40 CFR 52.2473).

Ecology and the Authority are to conduct a continuous surveillance program to monitor ambient air quality [WAC 173-400-120(1); General Regulation 80-7 of the Authority, Section 400-120(1)].

\subsubsection{Effluent Air Quality Standards}

Effluent standards govern emissions at the source. Although effluent monitoring is not within the scope of this report, the standards are briefly 
discussed here because they may influence environmental surveillance. For example, state and local regulations [WAC 173-400-120(1) and General Regulation 80-7] provide that owners of air pollution sources may be required to conduct ambient air monitoring and report the results to the appropriate agency.

\section{Prevention of Significant Deterioration (PSD) Program}

After litigation regarding Section 161 of the Clean Air Act, EPA was required to adopt a nondegradation policy for those areas in which the air was cleaner than the NAAQS (i.e., considered "in attainment") (Randle 1989). Most of Region 230 (including the Hanford site) is in attainment. EPA's PSD regulations appear at 40 CFR 52.21. For the most part, the EPA regulations have been incorporated into the WAC by reference (WAC 173-403-080).

Under Section 163 of the Clean Air Act, air regions that comply with the NAAQS must be categorized as one of three classes: Class I, allowing such little deterioration that it has the effect of prohibiting any substantial growth; Class II, allowing for moderate, well-controlled growth; and Class III, allowing additional pollution up to a secondary NAAQS standard (Randle 1989). Most of Region 230 (excluding wilderness areas) is considered Class II.

The PSD regulations require that a permit be obtained for certain new stationary sources of air pollution or modifications to existing sources [40 CFR 52.21(i)] if the sources are "major emitting facilities." Section 169(1) of the Clean Air Act defines this term to include certain specifically designated sources that have the potential to emit 100 short tons per year of any air pollutant and all other sources that have the potential to emit 250 tons per year of any pollutant. Further, the Authority's Genera] Regulation 80-7 requires the registration of any source with the potential to emit 100 tons per year of a polfutant that is subject to an ambient air standard.

The PSD regulations relate to environmental surveillance at Hanford because they establish maximum allowable increases in ambient air concentrations for particular pollutants and for particular air quality classifications 
[40 CFR 52.21(c)]. They also relate because applications for PSD permits are to include an analysis of ambient air quality in the area [40 CFR 52.21(m)] to show that the new emissions will not violate NAAQS increments.

EPA has issued quality assurance requirements for assessing ambient air quality in the PSD process ( 40 CFR 58, Appendix B). In addition to these requirements, the permit applicant must use the best available control technology for controlling pollutant emissions.

The Hanford Site currently has one PSD permit that covers the PUREX plant in the 200 East Area and the $\mathrm{UO}_{3}$ plant in the 200 West Area. (The permit was originally issued September 30, 1980, and modified January 16, 1987.) The permit was issued by EPA Region 10; however, any modifications to the existing PSD permit or new PSD permits for the Site will be issued by Ecology.

\section{National Emission Standards for Hazardous Air Pollutants. (NESHAPS)}

Section 112 of the Clean Air Act directs EPA to establish NESHAPS. Under Section 112, EPA is required to list hazardous air poliutants and establish emission standards for these pollutants, which it does at 40 CFR 61 . General provisions applicable to all sources of air pollutants determined by EPA to be hazardous are in Subpart $A$ of 40 CFR 61. The national emission standard for radionuclide emissions from DOE facilities is discussed in Chapter 4.0 of this report.

\subsection{DOE ORDER 5400.1}

Chapter IV of DOE Order 5400.1 contains air quality monitoring requirements for DOE operations. Specific requirements for environmental survei1lance monitoring for nonradiological air emissions are in Section $8(b)$ of Chapter IV of the Order. This section states that ambient air quality monitoring programs should

- establish background concentration levels of pertinent chemical species

- determine the highest concentrations of the pertinent pollutant species expected to occur in the vicinity of DOE operations 
- determine representative pollutant concentrations at areas where public health and other concerns should be considered

- evaluate the effects of emissions on ambient levels of pertinent contaminants.

When available, ambient air quality data gathered by states under the requirement at 40 CFR 58.20 are to be used to accomplish the preceding objectives.

Section 6 of Chapter IV directs that DOE sites develop a meteorological information/monitoring program. The program is to characterize atmospheric transport, diffusion conditions, and other atmospheric conditions needed for environmental surveillance and is to ensure compliance with regulatory requirements. 


\subsection{RADIOLOGICAL CONTROL STANDARDS}

This chapter discusses the standards that appear in statutes, regulations, DOE orders, and guidance governing radionuclides discharged to the environment as a result of Hanford operations. This chapter does not cover standards for occupational exposure.

The standards of greatest interest to environmental monitoring at Hanford are airborne radionuclide standards (Section 4.2.1), drinking water exposure limits (4.2.2), low-level waste disposal standards (4.2.3), and DOE Orders addressing environmental surveillance (Section 4.4 .4 ).

\subsection{BASIC REGULATORY CONCEPTS FOR RADIOLOGICAL PROTECTION}

Federal and state radiological control schemes seek to protect the public from two types of radiation dangers. First, nuclear sources may produce penetrating (gamma) radiation which may directly expose the public. Second, radiation from radionuclides may expose the public to radiation of all types via the air, drinking water, and ingestion pathways.

Radiation standards may be expressed either as radiation dose or concentration. Radiation dose limits are computed annualiy for any member of the public and are usually measured in millirems (mrem). Dose limits may be given for the whole body, a weighted average of organs, or a single organ. Most radiological controls use the dose limit method.

Concentration standards are set to limit the concentration of radioactivity in effluents or environmental media. Concentration standards are derived from radiation dose $l$ imits and, in theory, limit an effluent so that after following various environmental pathways the radionuclides contained in the effluent will not produce a radiation dose that exceeds the adopted 1 imit.

Most radiological protection focuses on actual exposure to the public from radionuclides in the environment, rather than on "end-of-pipe" emissions controls. Therefore, environmental monitoring is an essential component of a radiological protection program. Monitoring must not only measure radiation 
levels in air and water, but must provide data for modeling pathways through the environmental links that lead to exposure of people.

\subsection{RADIATION EXPOSURE AND CONCENTRATION LIMITS}

Standards for environmental release of radiation and resultant human dose are organized here by manner of release. DOE Order 5400.5, "Radiation Protection of the Public and the Environment," is organized similarly. Within each section below the applicable federal, state, local and DOE limits are described.

\subsubsection{Airborne Radionuclide Emission Standards}

Radionuclide emissions are regulated at the federal level under the Clean Air Act. Considered a hazardous pollutant, radionuclides are governed by NESHAP ruTes. On December 15, 1989, EPA amended its NESHAP regulations pertaining to DOE facilities (54 FR 51654). Regulations under 40 CFR 61, Subpart $H$, contain emission standards for radionuclides other than radon; Subpart $Q$ sets standards for radon emissions from DOE facilities. These regulations limit cumulative air emissions from DOE facilities to those amounts that cause an effective dose equivalent $(a)$ of $10 \mathrm{mrem} / \mathrm{yr}$ to the whole body. This new regulation limits emissions of radon-222 to no more than 20 picocuries $(p C i) / m^{2} s$ as an average for the entire source. Compliance with NESHAPS limits is determined by calculating the highest effective dose to any member at any offsite point where there is a residence, school, business, or office.

Washington State also regulates radionuclide emissions to the air. The state dose limit, adopted by both Ecology and the Department of Health, was the same as the EPA 1 imit (WAC 173-480-040; WAC 402-80-050) prior to its recent revision.

DOE Order 5400.5 includes derived concentration guides (DCGs) for airborne effluents at the source. Proposed DCGs were provided to the Hanford contractors through a May 6, 1987, memo from R. E. Gerton, Director of Environment, Safety and Health Division, DOE-RL (Jaquish and Bryce 1989). DOE

(a) An estimate of the total risk of potential human health effects from radiation exposure (Jaquish and Bryce 1989). 
has directed that with some adjustment, DCGs can be used to ensure that an air emission will not violate the exposure standard due to inhalation or skin exposure. However, DCGs do not account for all pathways of exposure and are not adopted as limits on emissions.

The U.S. Nuclear Regulatory Commission's (NRC) radiation protection regulations at 10 CFR 20 were written for NRC-licensed facilities. WhiTe not applicable to DOE facilities, the regulations may be useful in evaluating the comprehensiveness of the environmental surveillance program. Table II in 10 CFR 20, Appendix $B$, contains air concentration limits for radioactivity above natural background levels in effluents discharged to unrestricted areas. Limits are given for 257 individual radionuclides, natural uranium and thorium, and "other" radionuclides not included on the 1 ist of 257 . These 1 imits range from $2 \times 10^{-14}$ to $1 \times 10^{-4}$ microcuries per 1 iter of effluent and apply at the boundary of the restricted area. If the effluents are discharged within the restricted area, appropriate dilution, dispersion, and decay factors may be applied to determine the concentration at the boundary. Higher effluent limits may be approved if individuals offsite will not be exposed to concentrations of radioactive material exceeding the Table II limits.

\subsubsection{Radionuclide Emission Standards for Water}

Radionuclide emissions to surface water and groundwater are not directly regulated. The Supreme Court has held that source, special nuclear, and byproduct materials are excluded from the definition of "pollutant" under the Clean water Act, so they are not regulated through the NPDES process (Train $v$. Colorado Public Interest Research Group, 426 U.S. I, 1976). Nor do the Clean Water Act's federal ambient water quality criteria prescribe numerical limits on radionuclides in receiving water. However, the Safe Drinking Water Act's MCLS, which indirectly regulate emissions, include concentration and dose standards for radionuclides in drinking water.

State Ambient Water Quality Standards

Ecology regulations for Class $A$ waters require, as for toxic substances, that radionuclide concentrations be below those which significantly affect public health, cause acute or chronic harm to aquatic biota, or adversely 
affect any water use [WAC 173-201-045(2)(c)(vii)]. In addition, radionuclide concentrations in all classes of surface water are considered "deleterious" if they exceed 1/100th of the concentration limits for radiation protection specified at WAC 402-24-220 or WAC 173-201-035(ii). Because this area is among those that have been preempted from state regulation by the Atomic Energy Act, these regulations probably are not directly applicable to Hanford.

\section{Drinking Water Exposure Standards}

Radionuclides in drinking water are regulated primarily through dose Timits from the Safe Drinking Water Act. Federal dose limits require that the average annual concentration of man-made radionuclides not produce a dose equivalent of $4 \mathrm{mrem} / \mathrm{yr}$ to the whole body or any internal organ, assuming a daily intake of 2 liters of water from the drinking water source in question [40 CFR 141.16(a)]. The average annual concentration assumed to produce a total body or organ dose of $4 \mathrm{mrem} / \mathrm{yr}$ is $20,000 \mathrm{pCi} / \mathrm{L}$ for tritium and $8 \mathrm{pCi} / \mathrm{L}$ for strontium-90 [40 CFR 141.16(b)]. The state has adopted the same standard at WAC 248-54-175(9)(c). DOE Order 5400.5 adopts the same limit and applies it to all onsite water supplies, even "public drinking water supplies" not covered by the Safe Drinking Water Act.

Two types of concentration guidelines also apply to radioactive emissions to water: drinking water standards and DCGs.

Drinking Water Standards. These standards include a federal limit on gross alpha activity (excluding uranium and radon) of $15 \mathrm{pCi} / \mathrm{L}$ and on radium of $5 \mathrm{pCi} / \mathrm{L}$ (40 CFR 141.15) in drinking water. The state limits are the same, except that the state limit for radium-226 in drinking water is only $3 \mathrm{pCi} / \mathrm{L}$ and the alpha activity limit includes radon [WAC 248-54-175(9)(b). In addition, the EPA formerly calculated average annual concentrations of various radionuclides that yield an annual dose of 4 mrem to the most affected organ (National Interim Primary Drinking Water Regulations, Table IV-2A). The regulations now prescribe a method for calculating those concentrations [40 CFR 141.16(b)].

Derived Concentration Guides. DOE established DCGs for both air (Section 4.2.1) and water. The water guidelines are calculated to yield a dose 
equivalent of $100 \mathrm{mrem} / \mathrm{yr}$. Therefore, compliance with them does not assure compliance with drinking water exposure standards (4 mrem/yr). The DCGs were originally set forth in DOE Order 5480.1A and revised by a May 6, 1987, memorandum from DOE headquarters. DOE Order 5400.5 adopts the new DCGs as a standard to determine whether additional effluent treatment is required.

In short, a 1iquid effluent that will reach groundwater or surface water must meet the DCG limits, or must be treated by the best available technology, at the end of the pipe. By the time the effluent reaches a point of withdrawal for drinking water, the affected groundwater or surface water must meet drinking water exposure standards. The concentration limits provide an indication as to whether the exposure standards will be met.

\subsubsection{All Media}

No single statute limits total environmental exposure to radiation, a) though the NRC's 10 CFR 20 addresses this issue. In 1981, DOE adopted a standard of $500 \mathrm{mrem} / \mathrm{yr}$ in DOE Order $5780.1 \mathrm{H}$. That Order also included DCGs derived from that limit. However, the 1981 Order was modified by a DOE directive dated September 3, 1985, entitled "Radiation Standards for Protection of the Public in the Vicinity of DOE Facilities," which adopted the International Commission on Radiological Protection (ICRP) standard of $100 \mathrm{mrem} / \mathrm{yr}$. DOE Order 5400.5 al so adopts the ICRP standard. The ICRP standard requires that exposure be as low as reasonably achievable, considering economic and other factors, and that exposure to the public not exceed an effective dose equivalent of $100 \mathrm{mrem} / \mathrm{yr}$, nor a dose equivalent of more than $5 \mathrm{rem} / \mathrm{yr}$ to any organ. This includes exposure through all environmental media and direct exposure to penetrating radiation (except background and medical), from both from DOE and non-DOE sources.

The purpose of 10 CFR 20 is to ensure that the total dose from use of material arising out of activities conducted under licenses issued by NRC does not exceed the levels specified in 10 CFR 20.105 for unrestricted areas. Radiation levels in these unrestricted areas must not exceed either of the following limits:

- greater than $2 \mathrm{mrem} / \mathrm{hr}$ for an individual continuously present in the area 
- greater than $100 \mathrm{mrem}$ in 7 consecutive days for an individual continuously present in the area.

NRC may approve alternative limits if the license applicant demonstrates that the proposed limits are not likely to cause any individual to receive a wholebody dose greater than $0.5 \mathrm{rem}$ in any one calendar year.

\subsection{STAMDARDS GOVERNING WASTE MANAGEMENT}

The controls on radiation exposure from radioactive waste disposal also contain both general exposure limits and limits on specific pathways. These limits have been promulgated by EPA, NRC, and DOE.

\subsubsection{Environmenta] Protection Agency}

While the EPA regulations described below do not contain specific environmental monitoring requirements, the dose 1 imits imposed upon various activities conducted on the Hanford Site should be considered in the development and implementation of site monitoring programs. The following regulations apply to activities at Hanford:

40 CFR 191 Environmental Radiation Protection Standards for Management and Disposal of Spent Nuclear Fuel, High-Level and Transuranic

40 CFR 193 Environmental Standards for the Management, Storage and Land Disposal of Low-Level Radioactive Waste (inciuding Below Regulatory Concern criteria)

40 CFR 194 Residual Radioactive Materials Cleanup -- Radiation Protection Criteria (under development)

Most of the above regulations contain overall radiation dose limits for any member of the public exposed to radioactivity as a result of DOE or NRC waste management and disposal operations. In addition, some dose and effluent limits and environmental concentration limits are given for particular radionuclides.

(a) Subpart B, Environmental Standards for Disposal, was vacated by the First Circuit Court of Appeals and remanded to EPA for further consideration based on groundwater protection issues [NRDC v. EPA, 824 F.2d 1258 (First Circuit 1987)]. 
The overall dose standards contained in the 40 CFR 191 and draft 193 regulations limit the annual dose equivalent for any member of the public to 25 mrem to the whole body, considering all pathways of exposure. [40 CFR 190, which is applicable to the operation of licensed NRC nuclear power plants (such as WPPSS Unit 2), also contains this 1 imit, as well as an annual limit of 75 mrem to the thyroid and 25 mrem to any other organ.] 40 CFR 191 contains an annual limit of 75 mrem to any critical organ for radionuclides resulting from high-level waste (HLW) and transuranic (TRU) waste operations. The remanded groundwater protection requirements also include an annual limit of 4 mrem from the drinking water pathway, assuming a daily consumption of 2 liters of affected water from a significant source of groundwater. These regulations also contain effluent 1 imits for radionuclide release from a highlevel or transuranic waste disposal facility.

\subsubsection{Nuclear Regulatory Commission Regulations}

In general, NRC regulations are not applicable to DOE waste management operations for DOE-generated wastes. However, 10 CFR 6l, "Licensing Requirements for Land Disposal of [Low-Level] Radioactive Waste," applies to the lowlevel disposal facility operating at Hanford and may impact environmental surveillance.

The issuance of licenses for low-level waste (LLW) disposal is governed by 10 CFR 61. Performance objectives require that concentrations of radioactive material that may be released to the general environment via groundwater, surface water, air, soil, plants, or animals not result in an annual dose exceeding an equivalent of 25 mrem to the whole body, 75 mrem to the thyrojd, and 25 mrem to any other organ. The licensee at a land disposal facility must maintain a monitoring program to evaluate potential health and environmental impacts during facility construction and operation. The monitoring program must also enable evaluation of long-term effects and the need for mitigation. The monitoring system must provide warning of radionuclide releases from the disposal site before releases leave the site boundary. A monitoring system must also be maintained following site closure. 


\subsubsection{DOE Orders}

DOE promulgated two orders that specifically address radioactive and hazardous waste management: DOE 5400.3, "Hazardous and Radioactive Mixed Waste Program" (February 22, 1989); and DOE 5820.2A, "Radioactive Waste Management" (September 26, 1988). DOE 5400.3 contains administrative provisions but does not contain environmental monitoring requirements or standards.

DOE 5820.2A establishes policies and guidelines, including monitoring requirements, by which $D O E$ manages its radioactive and mixed waste and contaminated facilities. It states that surface water systems assocjated with HLW storage areas shall be monitored according to applicable NPDES permits and DOE Order requirements. For TRU waste, the Order requires that new RCRA interimstatus storage facilities have an environmental monitoring system to detect any release and migration of major radioactive and hazardous components. The Order further requires that background levels of primary radioactive and hazardous waste components be determined.

DOE Order 5820.2A states that LLW not previously disposed of must be managed to ensure that external exposure to the waste and concentrations of radioactive material which may be released into surface water, groundwater, soil, plants, and animals will not result in an effective dose equivalent of more than $25 \mathrm{mrem} / \mathrm{yr}$ to any member of the public. The LLW must be managed so that the committed effective dose equivalents received by individuals who may inadvertently intrude into the facility after the loss of active institutional control (100 years) will not exceed $100 \mathrm{mrem} / \mathrm{yr}$ for continuous exposure or 500 mrem for a single acute exposure.

Under Order 5820.2A, monitoring measurements to evaluate actual and prospective performance should be made at locations as required, within and outside each facility and disposal site, to support performance assessments. Monitoring should also be used to validate or modify the models used in performance assessments.

Under the Drder, each LLW treatment, storage, and disposal facility is to operate under an environmental monitoring program that conforms to DOE 5484.1 and meets the following requirements: 
- has the ability to measure operational effluent releases, migration of radionuclides, disposal unit subsidence, and changes in disposal facility and disposal site parameters that may affect long-term site performance

- includes, but is not necessarily limited to, monitoring surface soil, air, and water and subsurface soil and water, both in the saturated and unsaturated zones

- has the ability to detect changing trends in performance sufficiently in advance to allow corrective action. The monitoring progran must be able to ascertain whether effluents from each treatment, storage, or disposal facility or disposal site meet the requirements of applicable DOE Orders.

\subsection{MONITORING REQUIREMENTS}

Limits are based on exposure at the point of contact with people, rather than on point of emission. Environmental monitoring is necessary to ensure compliance with radiation limits in individual media, and also to enable the addition of other emitting sources. The discussion below reviews the federal, state and local requirements for different media, then reviews a comprehensive draft DOE order on radiation monitoring.

\subsubsection{Airborne Radionuclide Emissions}

Environmental surveillance is required to ensure compliance with exposure standards for airborne emissions under 40 CFR 61 and state equivalents. These regulations set forth sampling methodology for monitoring emissions and exposures to the public (40 CFR 61.93).

The Department of Health also has issued monitoring requirements, the "Monitoring and Enforcement of Air Quality and Emission Standards for Radionuclides" (WAC 402-80). These regulations apply to and require state registration of all DOE and other federally owned sources of airborne radionuclide emissions (WAC 402-80-060). Since 1988, the regulations have also required sources to obtain a permit to operate. At Hanford, such permits are to be issued by the state for each major production, processing or research area, rather than for each individual source (WAC 402-80-065). The regulations include monitoring requirements at WAC 402-80-080. In part, these state rules repeat the federa] regulations. They also provide that the state may conduct 
environmental surveillance and may require the operator of any facility to conduct stack sampling, ambient air monitoring, computer dose modeling and "verification." The use of continuous monitoring equipment is encouraged but not required. The state may also take its own sample of the emission source.

\subsubsection{Water Monitoring}

General requirements for environmental monitoring by NPDES permittees are described in Chapter 2.0. Primary monitoring for radionuclides in water, however, falls under the regulation of the Safe Drinking Water Act. Specific methods for determining compliance with the exposure and concentration limits explained above are prescribed at 40 CFR 141.25. All public drinking water supply systems must be monitored. Community water systems must be monitored periodically for gross alpha activity, radium-226 and radium-228 (40 CFR 141.26). For mining or other operations which may contribute alpha particle activity to either surface water or groundwater sources of drinking water, the state may order monitoring more frequently than every four years. More frequent monitoring is required if the alpha-emitters exceed certain limits, generally $3 \mathrm{pCi} / \mathrm{L}$ of water.

The regulations impose further monitoring requirements for manmade radioactivity, including initial monitoring of all community water systems serving more than 100,000 persons. Samples are analyzed for gross beta activity, tritium and strontium-90. No further sampling is required if the gross beta activity is less than $50 \mathrm{pCi} / \mathrm{L}$ and the two radionuclides are within their MCLs. The state, however, may order additional monitoring to determine the concentration of manmade radioactivity in principal watersheds.

Suppliers who use waters the state has designated as contaminated by effluents from nuclear facilities must monitor quarterly for gross beta activity and iodine-131 and annually for strontium-90 and tritium. More comprehensive analysis, including that for strontium-89 and cesium-134, is required if gross beta activity exceeds $15 \mathrm{pCi} / \mathrm{L}$. The state may allow the substitution of environmental surveillance data taken in conjunction with a nuclear facility to be substituted for direct monitoring of manmade radioactivity by a supplier [40 CFR 141.27 (b)(4)]. 


\subsubsection{State Monitoring for Licenses and Registrants}

The state radiation control system under RCW 70.98 and WAC 402 is primarily a registration and licensing program. Under WAC 402-16, regulated persons must either register any "radiation machine" [e.g., x-ray machines; see WAC 402-12-050(50)] under WAC 402-16, or obtain a license for radioactive materials. Many uses of radioactive materials are granted general licenses, under which an application is not required. Other uses require a special license which is granted on application (WAC 402-21, -22). The radiation protection standards in WAC 402-24 include exposure limits for "restricted" and "unrestricted" areas. Environmental monitoring is not expressly required to demonstrate compliance with the standards for unrestricted areas, but it is required if the licensee applies for permission to release more than the normally allowed amount to an unrestricted area [WAC 402-24-050(3)(f)]. However, the 1 icensee/registrant may be required to perform "surveys" in accordance with NRC Regulatory Guide 8.23 to demonstrate compliance (WAC 402-24-085). Likewise, WAC 402-12-10 allows the Department of Health to perform appropriate tests and "surveys." These requirements could include environmental monitoring.

In addition, RCW 70.98.050(4) requires the Department of Health to implement an "independent state-wide program" to monitor radiation exposure and develop an exposure baseline. Specifically, it must conduct environmental monitoring to "verify the adequacy and accuracy of environmental radiation monitoring programs" conducted by DOE (and private licensees). To operate this ambient monitoring system, the Department of Health collects fees from 1 icensees and from DOE based on its airborne emissions. In addition, funding for the state to monitor Hanford remediation is provided under the Tri-Party Agreement (see Chapter 5.0). These sections of the RCW relate to a state-run monitoring program and, therefore, do not directly affect monitoring requirements at Hanford. It is worth knowing, however, that the state will be performing its own independent monitoring to check what is done on the Hanford Site. 


\subsubsection{DOE Orders}

DOE Orders relating to radiological monitoring are in a state of flux. Currentiy, DOE Order 5400.1 includes environmental monitoring requirements. DOE Order 5400.5, which establishes radiation protection standards, al so requires monitoring and surveillance to demonstrate compliance with its requirements. Those monitoring requirements are spelled out in great detail in Draft DOE Order 5400.XY.

Draft Order 5400.XY establishes DOE policy to perform effluent monitoring and environmental surveillance to demonstrate compliance with applicable laws and DOE orders. Its requirements are extensive and include monitoring of a11 radiological liquid and atmospheric effluents, meteorological monitoring, environmental surveillance, and public radiation dose estimates. The liquid effluent monitoring requirements are to demonstrate that effluents meet OCGs at the point of release (a DOE standard, not a legal requirement). Air emission monitoring is to demonstrate compliance with EPA requirements. The Order details how to design a sampling system, which EPA has not yet prescribed.

The draft Order states that the objective of environmental surveillance is to monitor all environmental pathways that might lead to a dose equivalent of site origin. In addition, drinking water systems that may be affected are to be monitored in accordance with 40 CFR 141.26. Chapter $U$ of the draft Order describes how to monitor the various pathways of exposure, including direct radiation, air, water, terrestrial foodstuffs, aquatic foodstuffs, and sediment.

Some of this information is directly applicable to compliance. For example, when coupled with the appropriate computer model, air monitoring will determine whether the exposure standards are met. The data will be used primarily to fulfill requirements to calculate the public dose of radiation from DOE activities by accounting for all environmental pathways plus direct exposure.

DOE Orders 5484.1 and 5400.3 and Draft DOE Order 5400.XY require three types of radiation reports: exposure to the public "at the fencepost"; annual dose equivalent received by the hypothetical maximally exposed person; and 
total population exposure. These reports are all made part of the annual Hanford Site Environmental Report. 


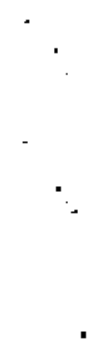




\subsection{HAZARDOUS WASTE STANDARDS}

Emissions to the environment from active and inactive hazardous waste sites at the Hanford Site and their cleanup are governed primarily by CERCLA (42 USC 9601-9657), and the RCRA (42 USC 6901-6987). Governing the detailed implementation of RCRA/CERCLA management and cleanup at Hanford is the Federal Facility Agreement and Consent Order (Tri-Party Agreement) signed by EPA, Ecology, and DOE on May 15, 1989. This Agreement is discussed at the end of this chapter.

Because immediate above-ground environmental monitoring of Hanford's hazardous waste facilities is to be conducted as part of the effluent monitoring program by Westinghouse-Hanford Company, this chapter contains only a brief discussion of this topic. CERCLA and RCRA groundwater monitoring requirements are discussed in detail in Keller et a]. (1989). For a summary of the legal framework for these and other environmental laws, see Appendix A.

\subsection{CERCLA/SARA}

Congress enacted CERCLA to address contamination at inactive and abandoned waste disposal sites. In doing so, congress created a sweeping scheme providing for liability, compensation, cleanup and emergency response for hazardous substances released into the environment.

Section 105 provides for a National Priorities List (NPL) of contaminated sites prioritized by EPA under a hazard ranking system. EPA has promulgated the NPL at 40 CFR 300 , Appendix B, which is updated with additional sites from time to time. The Hanford Site has been listed on the NPL, thus triggering a timetable for cleanup.

Several developments since the enactment of CERCLA in 1980 have resulted in major changes to the Superfund program. In 1986, Congress passed the Superfund Amendments and Reauthorization Act (SARA). SARA includes Section 120, which creates a number of federal agency responsibilities for the assessment and cleanup of government hazardous waste sites. 
SARA also mandated a major revision of the National $0 i l$ and Hazardous Substances Pollution Contingency Plan (NCP) (40 CFR 300). A revised NCP was finalized in February 1990. This was originally been proposed on December 21, 1988 (53 FR 51394). The revised NCP addresses selection of applicable or relevant and appropriate requirements (ARARs), sets forth in much greater detail the remedial investigation/feasibility study (RI/FS) process, and provides for greater cooperation between EPA and the states in implementing Superfund cleanups. The implications of the revised NCP with regard to environmental monitoring are discussed in detail below.

\subsubsection{Monitoring Requirements}

Monitoring requirements are triggered at a number of points in the CERCLA process described in the current NCP. However, the best source of information on how EPA will implement CERCLA in the future is in the revised NCP and in EPA guidance documents.

\section{Notification of Releases}

Routine environmental monitoring may identify a release of hazardous substances in reportable quantities. Thus, CERCLA's notification requirements are relevant to environmental monitoring. Detection and analys is of releases is an objective of the Hanford environmental monitoring program. Under CERCLA Sections 102, 103(a) and $103(\mathrm{~b})$, detection of release may require reporting to the National Response Center of the Coast Guard.

\section{Monitoring Under Remedial Investiqation/Feasibility Study} Project Scoping

Not later than six months after inclusion of any federal facility on the NPL, the agency that owns or operates the facility must, in consultation with $E P A$, begin an RI and FS for the facility. The purpose of the RI/FS is to assess site conditions and evaluate alternatives to select a remedy. Developing and conducting an RI/FS generally includes project scoping, data collection, risk assessment, and analysis of alternatives. Specific guidance for implementing this stage of the CERCLA process is found in the NCP and in EPA's 
"Guidance for Conducting Remedial Investigations and Feasibility Studies Under CERCLA," OSWER 9355.3-01 (Interim Final) (hereafter referred to as "RI/FS Guidance").

Under the NCP, RI/FS project scoping includes development of sampling and analysis plans and preparation of environmental surveillance requirements as part of site-specific health and safety plans (53 FR 51502). Limited data collection studies are also specified where this information would assist in scoping the RI/FS or accelerating response actions.

Site characterization is part of the RI process and can include sampling of groundwater, surface water, soil, air, biota, and soil gas. Chapter 3.0 of the RI/FS Guidance describes conducting field investigations, analyzing field samples and evaluating results as part of characterizing the contaminated site and developing a baseline risk analysis. A determination must be made regarding whether the data are sufficient to develop and evaluate potential remedial alternatives. Gathering and analyzing samples are discussed in EPA's "A Compendium of Superfund Field Operations Methods," OSWER Directive 9355.0-14 (September 1987). In addition to aiding the RI/FS process, site characterization data, including monitoring results, are provided by the lead agency to the Agency for Toxic Substances and Disease Registry for the preparation of health assessments.

\section{Screening of Remedial Alternatives}

Environmental monitoring must be considered in evaluating remedial alternatives at the feasibility study stage. The feasibility study required by NCP entails a detailed analysis of remedial alternatives that represent viable hazardous waste management approaches for a given site. Long-term management is required for any remedy that leaves untreated substances and/or treatment residuals at the site. The NCP requires each remedial alternative to be analyzed under nine criteria. Environmental monitoring is listed as a factor that must be considered, along with engineering and institutional controls, and operation and maintenance. 
Monitoring of Operation and Maintenance, Including Compliance With ARARs

Numerous types of remedial designs include environmental monitoring as an integral part of the operation and maintenance (08M) plan. Environmental monitoring is usually included where untreated substances and/or treatment residuals are left onsite, or where pumping and treating of groundwater is required. Monitoring measures the remedial action's effectiveness in containing the contamination and complying with ARARs.

Guidance for this phase of the CERCLA process is contained in EPA's "Superfund for Remedial Design and Remedial Action Guidance (Rev.)," OSWER 9355.0-4A (June 1986) (RD/RA Guidance). However, the RD/RA Guidance applies to Superfund-financed and potentially responsible party cleanups but not to actions conducted by federal agencies. EPA intends to publish a "federal facilities manual" that will provide direct guidance to federal agencies for $\mathrm{RD} / \mathrm{RA}$ activities.

\subsubsection{Emergency Planning and Community Right-to-Know Act (SARA Title III)}

Title III of SARA created a separate new statute, the Emergency Planning and Community Right-to-know Act of 1986. The purpose of Title III is to increase public access to information on the presence and release of hazardous chemicals into the environment. Title III establishes new requirements for industrial facilities and federal, state and local governments regarding emergency planning and reporting of toxic and hazardous chemicals.

The Title III provision most relevant to environmental monitoring and surveillance is the emergency notification requirement. State and local authorities (including the Emergency Response Commission of the State Department of Community Development) should be notified of a release of a listed hazardous substance at or above the reportable quantity. This reporting provision expands upon the spill-reporting requirements of Section 103(a) of CERCLA.

"Federally permitted releases," as defined in Section 101(10) of CERCLA, are not subject to the emergency notification requirements. A release of pollutants within the effluent limits contained in an NPDES permit is an example of such a "federally permitted release." 
The Title III reporting requirement is applicable to CERCLA "hazardous substances" listed at 40 CFR 402 and to SARA "extremely hazardous substances," 406 of which were listed by EPA on April 22, 1987 (52 FR 13378).

\subsection{FEDERAL RESOURCE CONSERVATION AND RECOVERY ACT}

RCRA, enacted in 1976 and significantly amended in 1980 and 1984, regulates the disposal of hazardous and nonhazardous "solid" waste on land. While CERCLA is directed at remediation of inactive or abandoned waste sites, RCRA provides for "cradle-to-grave" regulation of hazardous waste at active facilities.

RCRA is designed to be implemented primarily by the states. Almost all states, including Washington, have now received EPA authorization to run the basic RCRA program, but no states have yet been delegated authority for all of the varjous 1984 Hazardous and Solid Waste Act requirements, which amended RCRA. The Tri-Party Agreement provides for Ecology to take the lead at Hanford in enforcing RCRA requirements, including permitting, closure and post-closure requirements. RCRA corrective action requirements under the Hazardous and Solid Waste Act have not yet been delegated and thus would still be enforced by EPA under its regulations and the Trj-Party Agreement.

Washington State implements its EPA-approved RCRA Subtitle C program under the Washington Hazardous Waste Management Act (HWMA) (RCW 70.105), and Ecology's Dangerous Waste Regulations, (WAC 173-303). The state's program closely parallels RCRA but is stricter in several respects. Hazardous wastes are classed as dangerous wastes or extremely hazardous wastes under the regulations. Some wastes the state has designated "dangerous wastes" are not even included on RCRA's list of hazardous wastes. The State has placed stringent restrictions on the disposal of extremely hazardous wastes (RCW 70.105.050). The Hazardous Waste Management Act was amended in 1987 to grant Ecology the power to regulate mixed radioactive and hazardous wastes, "to the extent it is not preempted by federal law" (RCW 70.105.109). The hazardous component of such mixed waste is subject to regulation under RCRA, as long as such action is not inconsistent with the Atomic Energy Act (see 10 CFR 962; 53 FR 37045, September 23, 1988; RCRA Section 1006). 


\subsubsection{Hazardous Waste Management}

The hazardous waste management provisions of RCRA Subtitle $C$ are most relevant to the Hanford Site and environmental surveillance. The site contains a number of treatment, storage, or disposal (TSD) facilities that have been accorded "interim status" and are, thus, subject to the standards in 40 CFR 265 for interim status facilities.

Under Subtitle $C$, a solid waste is "hazardous" if it 1 ) is listed in one of several EPA lists (set forth in 40 CFR 261.31-33) or 2) exhibits at least one of the four characteristics of a hazardous waste [ignitability, corrosivity, reactivity, and extraction procedure (EP) toxicity].

If a solid waste is determined to be hazardous, then a facility is subject to RCRA's cradle-to-grave management system. Subtitle $C$ imposes limited requirements on hazardous waste generators and transporters, but imposes detailed, stringent standards on owners and operators of TSD facilities.

UnTess they qualify for "interim status" or for certain exemptions, all TSD facilities require RCRA operating permits. Upon closure, all land base units must obtain a post-closure permit, unless all hazardous wastes and hazardous constituents are removed from the unit ("clean closure").

RCRA's interim status provisions "grandfather in" existing facilities that were engaged in the treatment, storage or disposal of hazardous wastes as of November 18, 1980, or the date upon which a regulatory change made such facilities subject to RCRA. Comprehensive standards are established for interim status facilities (40 CFR 265) and TSD facilities (40 CFR 264).

Requirements for permanent and interim status facilities are similar. Both must meet general facility requirements such as recordkeeping, waste analysis, security, siting, emergency plans, closure, post-closure, etc. Both must also adhere to requirements specific to particular types of waste management units (incinerators, landfills, surface impoundments) and to a so-called miscellaneous unit. The miscellaneous unit would include certain Hanford waste units that do not readily fit within any other description. Specific environmental monitoring requirements for permitted and interim status TSD facilities are described below. 


\subsubsection{RCRA Corrective Action}

CERCLA and RCRA overlap in concept somewhat as a result of the 1984 Hazardous and Solid Waste Act amendments, which added corrective action requirements to RCRA. Under RCRA Sections 3004(u) and 3008(h), operating or post-closure permits for TSD facilities must include corrective action requirements for releases from any solid waste management unit anywhere on the facility. Similarly, EPA may require corrective action on any facility that has or has had interim status.

EPA is developing a comprehensive proposed rule setting forth the procedures and substance of the Section 3004(u) program. (The rule will become a new subchapter S of 40 CFR 264.) Cleanup standards under the Section 3004(u) program are expected to be consistent with the ARAR concept contained in CERCLA Section 121 and the NCP. The Tri-Party Agreement already provides for such consistency at Hanford.

A significant change made by the Hazardous and Solid Waste Act was the establishment of a national policy that land disposal should be the leastfavored method of handling hazardous waste [see RCRA Section 1002(d)(7)]. By May 1990, the 1and disposal of all untreated hazardous wastes will be prohibited unless EPA determines that certain exceptions apply on a site-by-site basis.

\subsubsection{RCRA Monitoring Requirements}

RCRA establishes groundwater compliance and monitoring programs for TSD facilities and interim status facilities. RCRA monitoring requirements have been addressed by Keller et al. (1989).

Releases from solid waste management units associated with RCRA facilities are subject to the MCLs, groundwater monitoring program, and corrective action requirements of 40 CFR 264 , subpart F. MCLs have been established for arsenic, barium, cadmium, chromium, lead, mercury, selenium, silver, endrin, lindane, methoxychlor, toxaphene, and 2,4,5-TP (40 CFR 264-94). The regulations set forth general monitoring requirements as well as detection monitoring and compliance monitoring programs (40 CFR 264.97 through 264-99). An owner or operator of a TSD facility must commence corrective action within a 
reasonable time to prevent hazardous constituents from exceeding their MCLS at compliance points (40 CFR 264.100). Monitoring is also an integral part of post-closure plans for surface impoundments, waste piles, land treatment units, and landfills (40 CFR 264.199).

Interim status facilities are also subject to groundwater monitoring requirements ( $40 \mathrm{CFR}, 265$, subpart F). The monitoring program must be capable of determining the facility's impact on the quality of the uppermost aquifer underlying the facility.

Ecology has promulgated a comprehensive groundwater protection regulation (WAC 173-303-645) paralleling that of EPA. The MCLS listed are the same as those in 40 CFR 264.94. Detection and compliance monitoring is included. See Keller et al. (1989) for additional discussion of this program.

\subsection{IRI-PARTY AGREEMENT}

The Tri-Party Agreement, signed on May 15, 1989, is a comprehensive setthement among DOE, EPA, and Ecology establishing a framework for environmental remediation at Hanford. The Tri-Party Agreement addresses both CERCLA and RCRA activities at the Site, including remedial and corrective action activities; delineates the respective roles of EPA and Ecology; and incorporates a detailed Action Plan that identifies, classifies and prioritizes past practice units where actions will be required.

Since RCRA and CERCLA management and cleanup schemes have potentially different coverage, cleanup standards, and most importantly, different enforcement agencies, such coordination of the agencies and programs was essential. The Tri-Party Agreement also provides an enforcement mechanism for the Action Plan, the technical plan for prioritizing and scheduling work among all the units at Hanford which require RCRA permits or CERCLA/RCRA remediation.

The Action Plan is an integral part of the Agreement. It describes in detail the methods and procedures for carrying out the Agreement and contains milestones for achieving major goals, such as RCRA permitting of all active units and closure of single-shell waste tanks. Investigation and remediation 
of inactive sites are scheduled according to starting dates for the RI/FS for some units, while others will be addressed on a rolling schedule according to their priority and available funding. Likewise, while some units are already prioritized, priorities among many sites must be set by later agreement.

\subsubsection{Coordination of Regulatory Schemes under the Agreement}

The Agreement coordinates CERCLA and RCRA regulatory schemes using the following principles:

- A11 RCRA permits, to the extent they require corrective action under the Hazardous and Solid Waste Act, will incorporate the remedial program in the Agreement. Ecology will be the final decisionmaker (barring appeals) on all RCRA permitting.

- Remedial action, whether undertaken under RCRA or CERCLA, is governed by one procedure and will meet consistent standards.

- To minimize the potential for conflict EPA and Ecology will agree on a lead agency for each unit and a dispute resolution procedure with a final decisionmaker for any given unit. (There is still the possibitity that EPA and Ecology may not agree on how to handTe a particular unit, in which case they reserve their independent authority.)

- The Agreement will also serve as the Interagency Agreement required by CERCLA Section 120, thus avoiding duplicative effort.

- The role of state law is preserved by incorporating its standards as ARARs.

\subsubsection{The Action Plan Approach}

Each individual waste site is assigned to an "operable unit" based on technical and practical criteria. The Action Plan divides all "operable units" onsite into TSD facilities, CERCLA Past Practice (CPP) Units, or RCRA Past Practice (RPP) Units. Some units have not yet been designated. TSD units are operating disposal sites which need RCRA permits both to continue to operate or to be closed. CPP units are inactive sites which will be addressed under CERCLA authority; RPP units will be addressed under RCRA authority. RPP units will generally include those associated with an active TSD unit, while CPP units will usually be entirely inactive. 
Consistent with the Agreement, the intent of the Action Plan is that CERCLA remediation and RCRA remediation will be functionally equivalent. Thus, for example, the Action Plan spells out that an RPP unit will address a11 CERCLA hazardous substances (not just RCRA hazardous waste), while CPPs will use RCRA (including state) standards as ARARs. The main effect of the distinction is to ensure there is only one final decisionmaker, EPA or Ecology, for each operable unit.

\subsubsection{Monitoring Requirements Under the Agreement and Action Plan}

General provisions related to monitoring are found in the text of the Agreement. First, Article XXX on Quality Assurance specifies that all sampling and analysis must comply with approved EPA methods, including "Interim Guidelines and Specifications for Preparing Quality Assurance Project Plans," and "Data Quality Objective Guidance." Analytical laboratories must meet EPA standards consistent with EPA QAMS-005/80. EPA and Ecology must approve DOE's QA/QC plans.

Article $X X X V$ on Sampling and Data/Document Availability requires all parties to make available the results of all sampling or monitoring conducted with respect to implementation of the Agreement. This does not include personnel or inside air monitoring, nor monitoring performed for air pollution rules or NPDES permits, but covers most soil and groundwater monitoring done at Hanford. Results must be available 45 days after the samples are taken unless $Q A$ is incomplete, in which case, preliminary results must be made available with quality-assured results within 90 days.

This Article also requires that DOE notify EPA and Ecology at least five days prior to well drilling, sampling, or other monitoring activity under the Agreement.

To comply with requirements for a RCRA final permit, each TSD unit must have a number of monitoring wells, which are set by regulation and permit. The Action Plan (Milestone M-24) spells out when the wells will be installed. Specific requirements are set forth for sampling the single-shell tanks as a TSD unit (Milestone M-10). Less specific requirements for monitoring apply as the TSD units move into the closure phase. If all hazardous wastes are not 
removed from the TSD facility at closure, the facility must be closed as a landfill, which requires a post-closure permit that includes a long-term monitoring plan.

Under the Action Plan, the many past-practice units will be addressed on a rolling schedule. Within six months after the Agreement is executed, the RI/FS process will begin on the highest priority site(s) in each of the four NPL-1isted areas. 0thers, either under CERCLA or the equivalent RCRA process, will follow, with $20 \mathrm{RI} / \mathrm{FS}$ work plans to be completed by 1992 . The schedule for the remainder depends on funding, but at least six will be undertaken each year.

Monitoring and sampling are a key part of the RI/FS process. The Action Plan recognizes that the specifics of sampling will be addressed by individual RI/FS work plans, each of which must contain a "sampling and analysis" element. Some sampling and analysis for scoping will precede development of the RI/FS work plan.

After the RI/FS is developed for a unit, a proposed plan will be approved, and the unit will move through the Remedial Design, Remedial Action, and 0\&M phases. The latter will include monitoring as specified in the 0\&M Plan. The Action Plan states that long-term monitoring is anticipated as part of the remedial action whenever waste or contamination is left in place. The need for further monitoring will be reviewed every five years.

The process for RPp units is similar, al though the phases have different names. The Corrective Measures Implementation phase may include long-term monitoring.

\section{Monitoring as an ARAR}

CERCLA requires that cleanups meet certain standards called ARARs. The parties specify that ARARs will also be used at RPP units remedied under RCRA. ARARs include not only cleanup levels for particular chemicals, but locationand action-specific requirements as well. Monitoring requirements from other federal and state laws may, therefore, become ARARs for a particular unit. 
The Action Plan specifically lists the state's radiation monitoring regulations as a possible source of ARARs. These regulations were discussed in Chapter 4.0 of this report.

\section{State Environmental Monitoring}

In addition to monitoring performed in connection with implementation of the Tri-Party Agreement, the state will conduct its own environmental monitoring program to check on the progress of work under the Tri-Party Agreement. In Article XXVIII, DOE agrees to pay those state costs incurred in connection with the Agreement that are not directly reimbursed as CERCLA costs, pursuant to a separate Mutual Cooperation Funding Agreement dated May 15, 1989. Under the Funding Agreement, the state "will implement an aggressive environmental oversight program . . [including] sharing of samples and data, public education and information exchange, and monitoring of air, soil, vegetation, wildlife, fish, foodstuffs, ambient radiation, and water in the environs of the Hanford site." DOE has agreed to fund this monitoring and oversight program. 


\subsection{REFERENCES}

Arbuckle, J. G., T. A. Vanderver, Jr., and Russell V. Randle. 1989. "Water Pollution Control." In Environmental Law Handbook, pp. 177-258. Government Institutes, Inc., Rockville, Maryland.

Findley, R. W. and D. A. Farber. 1985. Environmental Law: Cases and Materials, 2nd ed. West Publishing, St. Paul, Minnesota.

Jaquish, R. E. and R. W. Bryce, eds. 1989. Hanford Site Environmental Report for Calendar Year 1988. PNL-6825, Pacific Northwest Laboratory, Richland, Washington.

Keller, J. F., M. G. Woodruff, A. J. Schmidt, P. L. Hendrickson, and K. B. Selby. 1989. Regulatory Requirements Important to Hanford Single-Shel1 Tank Waste Management Decisions. PNL-6821, Pacific Northwest Laboratory, Richland, Washington.

Keller, J. F., A. J. Schmidt, and K. B. Selby, 1989. Regulatory Standards and 0ther Guidelines for Groundwater Monitoring Programs. PNL-6826, Pacific Northwest Laboratory, Richland, Washington.

King, S. E. 1989. Guidelines for Hanford Site Implementation of the National Environmental Policy Act. PNL-6755, Pacific Northwest Laboratory, Richland, Washington.

U.S. Environmental Protection Agency (EPA). 1985. The Technical Support Document for Water Quality-Based Toxics Control. EPA 440/4-85-032, Washington, D.C.

U.S. Environmental Protection Agency (EPA). 1984. Clean Air Act: Compliance/Enforcement Guidance Manual. Government Institutes, Inc., Rockville, Maryland.

U.S. Environmental Protection Agency (EPA). 1986. Quality Criteria for Water. Office of Water Regulations and Standards, Washington, D.C. 

APPENDIX A

BASICS OF ENVIRONMENTAL LAW 
APPENDIX A

\section{BASICS OF ENVIRONMENTAL LAW}

This appendix defines and describes the nature and interrelationships among environmental statutes, regulations, orders, agreements and other sources of authority that, when taken together, constitute the "1aw." This appendix also describes how authority is delegated by the federal government to state agencies under certain federal laws characterized as "flowdown schemes."

\section{A.I NATURE OF THE LAW}

Confusion arises from the several different forms that legal authority may take and the position of each form in the hierarchy of applicable law. For example, environmental statutes and regulations often address the same subjects, but in varying degrees of detail, and questions may arise regarding the one that governs in cases of conflict. Moreover, certain documents, such as DOE orders or other-agency guidance documents, may not be legally enforceable, yet they carry substantial authority in terms of compliance requirements. Monitoring requirements may be found in any of the forms of authority described below.

\section{A.1.1 Statutes}

Statutes are enacted by the U.S. Congress and state legislatures and, under the Constitution, are the law of the Tand. Federal statutes are enforceable against federal agencies and their contractors, as well as against states, local governments, and private citizens. Federal statutes can be found in the U.S. Code (USC) or the U.S. Code Annotated (USCA); Washington state statutes are found in the Revised Code of Washington (RCW). Regulatory schemes discussed in this report are all founded on environmental statutes such as the Comprehensive Environmental Response, Compensation and Liability Act (CERCLA), the Resource Conservation and Recovery Act (RCRA), the Clean Water Act, the Safe Drinking Water Act, and the Clean Air Act. Statutes 
enacted by state legislatures, such as the Washington Clean Air Act, are also legally enforceable. States may implement certain federat environmental statutes under the "flowdown schemes" discussed in Section A.2. A statute is the foundation for a particular regulatory scheme, which may include regulations, orders, decrees, agreements and policies.

\section{A.1.2 Requlations}

To attain the goals of environmental statutes passed by federal or state legislatures, federal or state administrative agencies often write regulations. Regulations are promulgated under the authority granted in statutes. They contain detailed procedures and stipulations for operating in compliance with the $1 \mathrm{aw}$ and are generally more directly related to the facilities that are regulated than are the statutes themselves. For environmental surveillance at Hanford, the most important regulatory agencies are the U.S. Environmental Protection Agency (EPA), the Washington Department of Ecology (Ecology), and the new Washington Department of Health.

Federal regulations first appear as "proposed rules" in the Federal Register (FR). Federal regulations are bound in volumes called the Code of Federal Regulations (CFR). Examples of EPA regulations are those that implement RCRA (40 CFR 260 through 271) and the National Contingency Plan for Implementation of CERCLA (40 CFR 300). A similar system exists for state regulations, which first appear in the Washington State Register and are bound in volumes called the Washington Administrative Code.

Regulations are as enforceable as statutes as long as they are judged to be congruent with the meaning of the statute. In the event of a conflict between a statute and regulation, the former controls. In some instances the courts may require a regulatory agency to revise its regulations because they are deemed insufficient to carry out the purposes of the statute under which they were written.

\section{A.1.3 Executive Orders}

Executive orders are orders issued from the President and are binding upon departments and other agencies of the Executive Branch of the federal government. For example, Executive order 12088 requires all federal agencies 
to comply with "applicable pollution control standards," which are defined to mean those that would apply to a private person. Executive orders are administratively enforceable within the Executive Branch. Executive orders are published in Title 3 of the Code of Federal Requlations.

\section{A.1.4 DOE Orders}

Likewise, orders of the U.S. Department of Energy are binding within that agency. Such orders do not, however, have the general force of $1 \mathrm{aw}$, and a conflict between an order and a regulation would be resolved in favor of the regulation.

\section{A.1.5 Enforcement Orders and Decrees}

Federal and state environmental laws are typically enforced by agencies and the courts through the issuance of various types of regulatory orders and decrees. Of particular interest are consent orders and consent decrees, which may impose binding requirements on governmental and private entities for the investigation, remediation and monitoring of contaminated sites. As the names indicate, such instruments require consent of the parties and constitute both an agreement and a binding court order. Federal and state enforcement agencies often have statutory power to issue non-consensual regulatory orders.

Section 120 of CERCLA (42 USC Section 9620) creates a unique procedure for the remediation of contaminated federal sites that culminates in an interagency agreement, also known as a federal facilities agreement. The Hanford Tri-Party Agreement is an example of such a document. Such compliance agreements are enforceable among the parties (EPA, Ecology and DOE) but do not, in themselves, constitute court orders directly enforceable by a court.

\section{A.1.6 Policies and Guidance}

Agencies may adopt nonbinding policy and guidance documents to assist others in complying with environmental laws. Examples are the EPA "Interim Guidance on Compliance with Other Applicable or Relevant and Appropriate Requirements" (52 FR 32496, August 27, 1987) and EPA's various guidance documents on conducting remedial investigations and feasibility studies under CERCLA. The State of Washington's "How Clean Is Clean" document is another 
example of such guidance. While these policies are generally nonbinding, agencies may use them to impose standards contained in such guidance or policies.

\section{A.2 FEDERAL FLOWDOWN SCHEMES}

Many of the major federal environmental statutes provide for delegation of enforcement and implementation responsibilities to state agencies under plans approved by EPA. The Clean Air Act, Clean Water Act, Safe Drinking Water Act, and RCRA provide that a state can administer and enforce the respective federal environmental programs, once EPA has delegated authority to the state. On occasion, there is a division of responsibility is divided between federal and state authorities. For example, Ecology administers the federal National Pollution Discharge Elimination System (NPDES) program in Washington State with respect to private dischargers, but EPA has retained authority to regulate point source discharges from federal facilities.

A flowdown scheme may result in only portions of a federal program being delegated to a state. Under RCRA, EPA has retained the power to administer and enforce all of the 1984 Hazardous and Solid Waste Act (HSWA) amendments; however, Ecology administers the remainder of the RCRA program under its dangerous waste regulations (WAC 173-303).

On the other hand, CERCLA is an example of a federal environmental statute that does not involve a flowdown scheme, although the State of Washington has taken the lead at certain CERCLA sites pursuant to agreement with EPA. Washington State voters, through the initiative process, have enacted the Washington Model Toxics Control Act (MTCA), which parallels the federal CERCLA on the state level. 


\section{APPENDIX B}

REFERENCE LIST FOR RELEVANT REGULATORY MATERIAL 
APPENDIX B

REFERENCE LIST FOR RELEVANT REGULATORY MATERIAL

\section{SURFACE WATER}

Statute/Regulation/Guidance and Subject

Clean Water Act

Ambient Water Quality Criteria

National Pollutant Discharge Regulations

Water Pretreatment Regulations

Reportable Quantities

Ambient Water Quality Criteria for Toxics

Discharges of $0 i 1$

Hazardous Substances

Water Toxics Control Program

Washington State Clean Water Act

Water Quality Criteria for 25 Toxics

Safe Drinking Water Act

Primary Drinking Water Standards (MCL/MCLG)

Proposed Additional MCLs

Washington State Clean Water Act

State MCLs and Monitoring Requirements

DOE Order(a)

General Environmental Surveitlance
Citation

42 USC 1251 et seq.

40 CFR 131

40 CFR $122-125$

40 CFR 403

40 CFR 117

40 CFR 129.1

40 CFR 110

40 CFR 116

54 FR 23868

RCW 90.48.010 et seq.

WAC 173-201-047

42 USC 300 (f) et seq.

40 CFR 141

54 FR 22062

RCW 43.20.050

WAC 248-54-175

(a) Applicable to PNL's Envirommental Surveillance Program.

B. 1 
AIR QUALITY

Statute/Regulation/Guidance and Subject

\section{CTean Air Act National Ambient Air Quality Standards NESHAPS \\ Washington State Clean Air Act \\ State Ambient Air Standards \\ Continuous Surveillance Program \\ Monitoring and Emissions \\ DOE Order \\ Monitoring Requirements} Maximum Allowable Increases and PSD Permits
Citation

42 USC 7401 et seq.

40 CFR 50

40 CFR 52

40 CFR 61

RCW 70.94

WAC $173(470-481)$

WAC $173-400-120$

WAC 402-80

5400.1 


\section{RADIOLOGICAL CONTROL SUBSTANCES}

Air

Statute/Requlation/Guidance and Subject

Clean Air Act

Emission Standards for Radionuclides

Washington State Clean Air Act

Ambient Air Standards

Monitoring and Emissions Standards

DOE Order

Derived Concentrations Guides - Air

NRC

Radiation Protection Regulations

\section{Water}

Safe Drinking Water Act

Primary Drinking Water Standards (MCL/MCLG)

Washington State Clean Water Regulations State MCLs

Radionuclide Concentrations

Radionuclide Concentrations

DOE Order

Derived Concentration Guides-Water

\section{All Media}

NRC

Environmental Exposure Limits

OOE Order

Standard for Radiological Protection

\section{Citation}

42 USC 7401 et seq.

40 CFR 61

RCW 70.94

WAC $173-(470-481)$

WAC $402-80$

5400.5

10 CFR 20

42 USC $300 f$ et seq.

40 CFR 141

RCW 43.20.050

WAC 248-54-175

WAC 402-24-220

WAC 173-201-035 (Note 2)

5400.5

10 CFR 20

5400.5

B. 3 


\section{RADIOACTIVE WASTE}

Statute/Requlation/Guidance and Subject

Resource Conservation and Recovery Act Dose Limit for Spent, HLW and TRU Waste Dose Limit for Low-Level Radioactive Waste Dose Limit for Radioactive Materials Cleanup

Dose Limit for Licensed NRC Plant

NRC

Licencing Requirements and Surveillance

DOE Order

Mixed Waste Monitoring Requirements
Citation

42 USC 6901 et seq.

40 CFR 191

40 CFR 193

40 CFR 194

(under development)

40 CFR 190

10 CFR 61

$5820.2 \mathrm{~A}$ 
HAZARDOUS WASTE

Statute/Regulation/Guidance and Subject

Citation

CERCLA (Superfund)/SARA Title III

42 USC 9601-9657

RI/FS Guidance

ARARS

Emergency Reporting Hazardous Substances

OSWER 9355.3-0I

OSWER 9234.1-01

40 CFR 402

Remedial Design and Remedial Action

Guidance, EPA

OSWER 9355.0-4A

Guidance for Conducting Remedial

Investigations and Feasibility Studies

Under CERCLA, EPA

OSWER 9355.3-01

Compendium of Superfund Field Operations Methods, EPA

OSWER 9355.0-14

Resource Conservation and Recovery Act Groundwater Monitoring (MCLs) Interim Status Standards

42 USC 6901-6987

40 CFR 264

40 CFR 265

Washington State Hazardous Waste Management Act Groundwater Protection Standards

RCW 70.105

WAC $173-303-645$ 
.

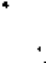




\section{DISTRIBUTION}

No, of

Copies

OFFSITE

2 DOE/Office of Scientific and Technical Information

\section{$\underline{\text { ONSITE }}$}

11 DOE Richland Operations Office

M. J. Anthony

E. A. Bracken

G. J. Bracken

J. J. Broderick

R. M. Carosino

R. D. Freeberg

R. E. Gerton

R. A. Holten

A. J. Knepp

E. C. Norman

M. W. Tiernan

12 Westinghouse Hanford Company

M. R. Adams

L. C. Brown

G. D. Carpenter

C. Defigh-Price

K. R. Fecht

K. A. Gasper

R. E. Lerch

H. E. McGuire

L. L. Powers

S. A. Wiegman

R. D. Wojtasek

D. D. Woodrich
No. of

Copies

56 Pacific Northwest Laboratory

R. C. Adams

S. P. Airhart

C. D. Becker

W. J. Bjorklund

B. N. Bjornstad

T. M. Brouns

R. W. Bryce

M. A. Chamness

D. R. Dahl

J. F. Falco

C. A. Geffen

R. E. Gephart

T. J. Gilmore

S. M. Goodwin

R. H. Gray

S. H. Hall

M. S. Hanson

P. L. Hendrickson

E. J. Jensen

B. J. Kaiser

J. F. Keller

S. E. King (5)

G. V. Last

R. E. Lundgren

S. P. Luttrell

P. J. Mitchel1

I. C. Nelson

R. Schalla

A. J. Schmidt

K. B. Selby

M. R. Siegel (10)

R. L. Skaggs

R. M. Smith

S. L. Stein

S. S. Teel

E. J. Westergard

M. G. Woodruff

Publishing Coordination

Technical Report Files 


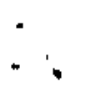

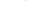

$\checkmark$ 